REVISTA DE DERECHO UNED, NÚM. 7, 2010

\title{
TRANSMISIÓN Y RESERVA DE LA PROPIEDAD EN EL CONTRATO DE COMPRAVENTA (I) ${ }^{1}$.
}

\author{
David Camacho Alonso
}

Doctor en Derecho

Resumen: La reserva del dominio, importante garantía en el tráfico alemán de bienes muebles, plantea numerosos problemas dogmáticos, en gran medida enraizados en la polisemia o vaguedad de conceptos romanos que hoy representan la columna vertebral de los Códigos de Derecho Privado de nuestra tradición jurídica. Este trabajo contribuye a determinar el significado y función de tales conceptos nucleares, como traditio, possessio, iusta causa o, incluso, el propio concepto de propiedad. En efecto, el estudio del origen y la función de tales conceptos en el Derecho Romano clásico contribuye a simplificar el debate en torno a problemas que típicamente se plantean en la reserva del dominio, como la función de la entrega en el proceso transmisivo, el papel de la voluntad de las partes o la posibilidad de condicionar los efectos de la entrega. Además, se expone el mecanismo por el que los romanos alcanzaron la finalidad garantista que hoy persigue la reserva del dominio: la combinación de causas.

Abstract: The retention of property, an important guaranty in the German economic traffic posses countless theoretical problems, largely rooted on the polysemy or vagueness of roman concepts that nowadays constitute the backbone of the private law codes of our legal tradition. This paper contributes to determine the meaning and role of these core concepts, such as traditio, possessio, iusta cusa, or even the concept of property itself. In fact, the study of the origin and role of such concepts in classic roman law contributes to simplify the debate about problems that typically arise around retention of prop-

${ }^{1}$ El presente trabajo constituye la primera parte de una serie de tres trabajos dedicados a estudiar el concepto de propiedad, su transmisión y su eventual retención (reserva del dominio) en las diferentes etapas del Derecho (clásico, intermedio y vigente). 
erty, such as the role of delivery in order to convey property, the role of the will of the parties or the possibility to make the acquisition of property conditional on the payment. Furthermore, the mechanism whereby Romans achieved the purpose of retention of property, namely, the combination of causes, is also explained.

Palabras clave: Reserva de dominio; Eigentumsvorbehalt; pactum reservati dominii; transmisión de propiedad.

Key words: Retention of property; Eigentumsvorbehalt; pactum reservati dominii; conveyance of property.

Sumario: I. La compraventa.-1. La compraventa en el Derecho romano clásico.1-.1 Introducción.-1.2. Las obligaciones del vendedor --1.3. Sobre la obligación del vendedor de procurar la propiedad al comprador.-1.3.1. Notas sobre la noción romana de propiedad.-1.3.2 La obligación de transmitir la propiedad al comprador.-1.4. El pago del precio y la transmisión de la propiedad.-1.5. Las consecuencias del impago del precio.-1.6. Mecanismos alternativos para proteger al vendedor frente al impago.-1.6.1. Entrega por causa no encaminada a la transmisión del dominio.-1.6.2. La lex commisoria.-1.7. Conclusiones.-II. La transmisión de la propiedad.-1. El concepto de dominio y su transmisión en las diferentes etapas del Derecho Romano .-1.1 Derecho romano clásico.-1.1.1. La transmisión de la propiedad a través de la mancipatio e in iure cessio.-1.1.2. La transmisión de la propiedad a través de la traditio ex iusta causa.-1.2. Derecho justinianeo--1.3 Conclusiones; Bibliografía.

\section{LA COMPRAVENTA}

\section{La compraventa en el Derecho romano clásico}

\subsection{Introducción}

El concepto de compraventa nace con la generalización en el uso del dinero. Su distinción respecto de la permuta es, por lo tanto, netamente formal, pues sólo se separa de ésta en que la contraprestación del comprador consiste en la entrega de aquel objeto al que convencionalmente se le atribuye un valor de cambio (dinero) ${ }^{2}$.

2 Paulus 33 ad ed. D.18,1,1pr.: «Origo emendi vendendique a permutationibus coepit. Olim enim non ita erat nummus neque aliud merx, aliud pretium vocabatur, sed unusquisque secundum necessitatem temporum ac rerum utilibus inutilia permutabat, 
El testimonio más antiguo que tenemos de compraventa en el Derecho romano nos lo proporciona el ritual de la mancipatio. Aunque en época clásica este ritual cumplía funciones distintas a las primigenias, ${ }^{3}$ de las palabras y de los gestos que constituyen la forma del acto podemos concluir sin lugar a dudas que la originaria mancipatio era una compraventa formal de contado -Gayo se refiere a la mancipatio nummo uno como a una imaginaria venditio y al nummus unus entregado como "quasi pretii loco» ${ }^{4}$ - en la que las prestaciones se cumplían simultáneamente y el precio que se pagaba era real ${ }^{5}$.

quando plerumque evenit, ut quod alteri superest alteri desit». Sabino y Cassio (también Gayo, de la escuela sabiniana [G. 3,141]) opinan que hay compra y venta en un trueque de toga por túnica -basándose en versos de Homero-(Paulus 33 ad ed. D.18,1,1); Nerva y Próculo, por el contrario, lo consideran permuta. Paulo se adhiere con razón a esta segunda opinión porque en la permuta no se distingue quién es el comprador y quién el vendedor, lo cual demuestra que la permuta es género y la compraventa especie, como pensaban los proculeyanos. Al respecto apunta A. FERNÁNDEZ DE BUJÁN (El precio como elemento comercial en el emptio-venditio romana, Madrid, 1984 , p. 27) que los juristas romanos reconocieron la precedencia histórica de la permuta, centrándose el debate más bien en cuál de las dos fue anterior una vez elevadas a la categoría abstracta de contrato, controversia que finalmente se resolvió a favor de los proculeyanos por la aceptación de la evidencia de que el precio sólo puede consistir en dinero. Sobre esta cuestión, GLÜCK, C.F. Ausführliche Erläuterung der Pandecten nach Hellfeld, Band 16,2, Erlangen, 1815, p. 2; en la literatura moderna, KASER, M. / KNÜTEL, R. Römisches Privatrecht (RPR), 18 Auf., C.H. Beck, Múnich, 2005, p. 206.

3 La mancipatio clásica en la que el pago del precio se representa con el golpeo de un trozo de bronce en la balanza (mancipatio nummo uno) ya no es una compraventa, sino un negocio jurídico abstracto que se utilizaría para transmitir la propiedad independientemente de la causa. Al respecto, D'ORS, Á. Derecho Privado Romano, Eunsa, Pamplona, 1986, pp.214-215; DIÓSDI, G. Ownership in Ancient and Preclassical Rroman Law, Akadémiai Kiadó, Budapest, 1970, p. 74: «La historia muestra que el conservadurismo es generalmente un factor obstaculizador del progreso, pero, como consecuencia de la dialéctica del fenómeno, sucede que el conservadurismo puede -involuntariamente- servir al progreso. Esto es lo que ocurrió con la mancipatio. Los pontífices, rígidamente anclados a las viejas fórmulas, optaron por privar a la mancipatio de su carácter de venta, a través de un precio simbólico y otras modificaciones superficiales que le hicieran apta para otros propósitos legales. Este paso resultó ser de una importancia histórica inmensa. Los intrépidos sacerdotes -inconscientemente, por supuesto- crearon el primer tipo de acto de disposición, independiente del contrato obligatorio...».

${ }_{4}$ G. 1,113/119; KASER, M. Eigentum und Besitz im älteren römischen Recht, $2^{\mathrm{a}}$ ed., Böhlau-Verlag, Colonia-Graz, 1956, p. 108. La mancipatio nummo uno es una «imaginaria venditio» porque no ha habido consentimiento sobre el precio, requisito básico para que exista un contrato de compraventa. Al respecto, FERNÁNDEZ DE BUJÁN, A. El precio..., pp. 57-58, basándose en Ulp. 31 ad. Sab. D. 50,17,16; Paul. 2 ad. ed. D. 18,1,55; Mod. 5 Reg. D. 44,7,54.

${ }_{5}$ ZIMMERMAN, R. The law of obligations, Juta \& C.H. Beck, Ciudad del Cabo / Múnich, 1990, p. 237; IGLESIAS, J. Derecho Romano, 11 a ed., Ariel, Barcelona, 1998, p. 255: «La mancipatio de los primeros tiempos es una compraventa real, que se sustancia en el cambio inmediato de la cosa y el precio». 
La posibilidad de aplazar el pago del precio, que se verifica ya desde una época bastante temprana -las doce tablas ya dan testimonio del aplazamiento del pago en la mancipatio ${ }^{6}$ - encontraría su fundamento último en la fides ${ }^{7}$.

La compraventa arcaica formal de la que oímos el eco en el ritual de la mancipatio $^{8}$ se circunscribió probablemente a las res mancipi. Para el resto de cosas se debía recurrir al mero intercambio (informal) de la cosa por el dinero'. Durante la república tardía la compraventa formal desapareció y en su lugar se fue configurando un contrato de compraventa consensual con eficacia puramente obligacional ${ }^{10}$.

\subsection{Las obligaciones del vendedor}

Las dos principales obligaciones del vendedor en la compraventa romana clásica eran: i) entregar la cosa al comprador ${ }^{11}$ y ii) indemnizarle en caso de evicción ${ }^{12}$.

${ }^{6}$ Tab. VII,11 (tal y como se recoge en DOMINGO, R. (Coord.) Textos de Derecho Romano, Aranzadi, Navarra, 2002, compendio basado a su vez a este respecto en la séptima edición de la obra de C.G. BRUNS, Th. MOMMSEN y O. GRADENWITZ: Fontes iuris Romani antiqui. Pars prima: Leges et negotia, $7^{\text {a }}$ ed., Tubinga, 1909). Volveremos sobre esta norma al estudiar I. 2.1.41; KASER, M. Eigentum..., p. 203.

7 Sobre el significado de fides en las XII Tablas, así como en Pomponius 31 ad q. muc. D. 18.1.19 ó en I. II, 1,41 véase infra, I,1,4, p. 13.

8 KASER, M. «Neue Studien zum altrömischen Eigentum», SZ (68), 1951, p. 149: «Hoy más bien nos inclinamos por la consideración de que la vindicatio en el sentido de contienda formal estuvo limitada a la res mancipi ... Sería de hecho extravagante haberse molestado en iniciar la contienda solemne sobre algo insignificante y de reducido valor económico. La imagen de dos dignos ciudadanos romanos que acuden ante el pretor y en ceremonioso gesto colocan su hasta, digamos, sobre una gallina, dando comienzo a sus vindicaciones rituales y depositando los sacramentos, limita lo grotesco».

9 De hecho, Gayo (2 rer. cott. D.41,1,9,3; Inst. 2,1,40) considera la traditio como derecho de gentes, porque «nihil enim tam conveniens est naturali aequitati, quam voluntatem domini volentis rem suam in alium transfere, ratam habere»

${ }^{10}$ En un primer lugar el régimen jurídico de la mancipatio se reproduce a través de la estipulación del duplo ; más tarde la compraventa se estandarizaría por obra de los ediles curules y no es necesario introducir expresmente la estipulación. Sobre esta evolución, KASER, M. / KNÜTEL, RPR. p. 203 ss.

${ }^{11}$ Ulpianus 32 ad ed. D.19,1,11,2: «Et in primus ipsam rem praestare venditorem oportet, id est tradere; quad res, si quidem dominus fuit venditor, facit et emtorem dominum, si non fuit, tantum evictionis nomine venditorem obligat, si modo pretium est numeratum, aut eo nomine satisfactum. Emptor autem numos venditoris facere cogitur.» Sobre las obligaciones del vendedor, GLÜCK, Ausführliche Erläuterung..., pp. 97 ff. ; más modernamente, KASER, M. / KNÜTEL, R. RPR, pp. 323-324. Nótese que la transmisión de la propiedad se concibe, por tanto, como algo aleatorio. Tal tibieza contrasta con el hecho de que se afirme rotudanemente que el comprador ha de hacer el dinero del vendedor, lo cual responde a que no es dable vindicar lo consumido.

${ }^{12}$ El presupuesto de la evicción es la satisfactoria reivindicación de un tercero, lo 
Conviene, no obstante, relativizar la importancia de la obligación de entregar la cosa al comprador. De hecho, si el vendedor debe entregar la cosa no es sólo -ni principalmente- porque a través del contrato de compraventa venga obligado a ello (p.ej., en la venta con deductio de usufructo no está obligado -de momento- a entregarla) ${ }^{13}$, sino fundamentalmente porque todo tenedor de cosa ajena sin título que apoye su tenencia -causa retinendi- ${ }^{14}$ viene obligado a entregársela a su dueño.

Además, en el periodo clásico del Derecho romano, al comprador le interesa más bien la «entrega» de la possessio ${ }^{15}$ concepto que deja de referirse a la ocupación nec vi del ager publicus cuando este se privatiza $(109 \mathrm{aC})^{16}$ para devenir uno de los conceptos más confusos del

cual tiene diferentes formulaciones procesales: Pomponius 9 ad sab. D. 21,2,16pr/1: "Duplae stipulatio committi dicitur tunc, quum res restituta est petitori, vel damnatus est litis aestimationes, vel possessor ab emtore conventus absolutus est»; Ulpianus 29 ad sab. D.21,2,21 pr.:»Si servus venditus decesserit, antequam evincatur, stipulatio non committitue, quia nemo eum evincat... »; el mero hecho de que el tradens no sea dominus -se descubrió nulidad o hurto en su cadena de causae dominii- no justifica per se la demanda por evicción; hay que esperar a la reivindicatio (Paulus 2 ad ed. aedil. curul. 21,2,41,1 -un comprador de esclavo deviene propietario a posteriori por otra causa diferente-testamento-, luego, a pesar de que le vendieron una cosa ajena, no se la pueden reivindicar: «quoniam evinci ei non potest, nec ipse sibi videtur evincere, non committitur duplae stipulatio»; la stipulatio duplae se pacta en la traditio para garantizar al accipiens una indemnización por el duplo en caso de evicción, tal y como de suyo ocurría en la mancipatio a través de la actio auctoritatis; sobre esta identidad de efectos, KASER, M. Eigentum..., p. 204 ss; BURDESE, A. Diritto Privato Romano, $3^{\text {a }}$ ed., Utet, Turín, 1990, p. 457.

${ }^{13}$ En el marco de la mancipatio se afirmaba Aio hunc fundum meum esse deducto usu fructu, citado por IGLESIAS, J. Derecho Romano, p. 255, apoyándose en FV. 50 .

${ }^{14}$ Emplea el giro, p.ej., Á. D'ORS (DPR, p. 226). Es ilustrativo, pero no conviene atribuirle un significado técnico porque las partes pueden alegar la misma causa tanto para fundar una pretensión reivindicatoria como para paralizar la reivindicatio de otro. En otras palabras: una misma causa puede ser retinendi o vindicandi en función de la posición procesal que se asuma.

${ }^{15}$ TALAMANCA, M. Istitutioni di Diritto Romano (IDR), Giuffrè, Milán, 1990, p. 586, basándose en Paulus 32 ad ed. D.19,4,1 pr.: «assumersi la garenzia per l'evizione, trasferire il possesso [della cosa]...» KASER, M. / KNÜTEL, R. RPR, p. 121: «Pero ya desde tiempos de los preclásicos se ve en la traditio (en sentido técnico) un negocio jurídico de transmisión (Übereinigungsgeschäft) consistente en el otorgamiento de la posesión (Besitzverschaffung) y una válida relación de atribución...».

16 Homo, L. Nueva historia de Roma, Iberia, 1981, Barcelona, p. 153: «Una primera ley suprime la inalienabilidad de los lotes. Muchos de los nuevos propietarios -cultivadores contra su propia voluntad- se apresuran a venderlos, generalmente a capitalistas, que se aprovehcan de la ocasión para realizar fructuosas colocaciones de dinero, y el doble daño al cual los Gracos habían intentado poner remedio -la extensión de la grande propiedad y el aflujo a Roma de los pequeños propietarios rurales-reaparece en seguida más grave aún que en el pasado. Una segunda ley, la ley Toria, en 
Derecho privado ${ }^{17}$. No obstante, de un análisis inductivo de casos en los que se concede o deniega la posesión podemos inducir que es possessor aquél que aparece frente a la sociedad como propietario, bien i) porque tiene la cosa físicamente consigo (supuesto ordinario: poseedor con corpus), o bien ii) porque se le reconoce socialmente como tal, tenga o no tenga el corpus: ii') si lo tiene, se le negará el animus (v.gr., el menor ${ }^{18}$ durmiente o furiosus ${ }^{19}$ que sostiene algo ${ }^{20}$ el preso respecto de los grilletes que «le llevan $\left.{ }^{21}\right)$, ii") si no tiene el corpus, se le atribuirá la posesión, igualmente, por el animus, siempre que de acuerdo con la percepción social se le reconozca una expectativa fundada a seguir teniendo para sí ( p.ej., cazador que persigue una presa que ha herido 22 -hasta que pierda el rastro- o que incluso ha atrapado en un $\operatorname{lazo}^{23}$, dueño de un animal con animus reverten$d i,{ }^{24}$ o comprador de un montón de leña que pone a un vigilante de su confianza $^{25}$. Aquí caben también las adquisiciones de la posesión por

111, puso fin a las distribuciones de tierras y conservó en manos de los ocupantes, con la sola condición del pago de un vectigal, las porciones del dominio público de que eran todavía detentadores. En fin, una tercera ley, en 109, transformó definitivamente las ocupaciones de tierras en propiedades privadas. Por esta última medida, la mayor parte del ager publicus se halla en adelante alienada, y, esta vez, con la garantía formal de la ley. Convertidos plenamente en propietarios, los ocupantes antiguos y los nuevos quedan desde entonces al abrigo de toda tentativa agraria ulterior. No solamente la legislación de los Gracos está muerta, sino que, hecho más grave todavía, a consecuencia de esta liquidación sistemática ya no hay ley agraria de grande envergadura que sea posible en adelante. La solución agraria ha fracasado»

${ }^{17}$ Los principales factores que inciden en la difícil aprehensión de este concepto son i) la variación de su significado a lo largo de las diferentes etapas del Derecho y ii) su combinación con conceptos igualmente vagos (bona fides, causa, iustum, o-sobre todo, animus-). Sobre la interpretación de F.K. von SAVIGNY y de R. von IHERING sobre este último concepto, FERnÁndez De BuJán, A, DPR, pp. 350 y ss., quien señala la percepción subjetiva del primero y más objetiva del segundo, no exentas en todo caso de crítica: en cuanto al primero, resulta discutible la noción de posesión derivada (Abgeleitetes Besitz) y en cuanto al segundo, no explica satisfactoriamente la posesión de los arrendatarios, depositarios, usufructuarios y comodatarios.

${ }_{18}^{18}$ Paul. 54 ad ed. D.41.2.1.3.

19 Paul. 54 ad ed. D. 41,2,1,10 / Celsus 23 D.41,2,18,1

20 No obstante, en estos casos también se dice que carecen de affectio tenendi (Paulus 54 ad ed. D.41,2,1,3) o intellectio possessionis (idem, D.41,2,1,3/9)

${ }^{21}$ Es un ejemplo posterior de F.K. Von SAVIGNY (Tratado de la posesión, Comares, Granada, 2005, p. 139.)

${ }_{22}$ G. 2 rer. cott. D. $41,1,5,1$

${ }^{23}$ Proc. 2 epist. D. $41,1,55$

${ }^{24}$ G. 2 rer. cott. D.41.1.5.5; dada la imposibilidad de adentrarse en el animus revertendi del animal es razonable pensar que sólo estaría permitida la adquisición por ocupación de los animales que parezcan perdidos.

${ }^{25}$ Jav. 5 ex post. lab. D. $41,2,51$

${ }^{26}$ Estos casos de possessio a través de personas sometidas al poder del pater o que 
esclavos o mandatarios $)^{26}$. Finalmente, a pesar de no gozar de la apariencia externa de propietario también se considera a alguien possessor iii) cuando es fácticamente imposible que la cosa vaya a parar a manos de otro (v.gr., comprador de fundo o mercancías a quien se le entregan las llaves [traditio clavium], comprador de columnas situadas en su ámbito de poder, ${ }^{27}$ poseedor de un tesoro enterrado en su fundo, ${ }^{28}$ de un objeto tirado por la borda,,$^{29}$ o de un bosque en invierno. ${ }^{30}$

El interés del causahabiente en adquirir la posesión responde a que tal condición jurídica permite el ejercicio del interdicto, que coloca a quien lo ejercita en una posición procesal privilegiada que le exime de demostrar el tracto sucesivo de causas del dominio. ${ }^{31} \mathrm{Si}$ tuado el centro de gravedad en el concepto de possessio por la importante función procesal que le corresponde, la necesidad de entrega en sentido estricto, de traditio, pasa a un segundo plano. No obstante, por esa tendencia casi religiosa a conservar formalidades jurídicas, la traditio aparece desnaturalizada en diferentes formas que tienen como común denominador hacer possessor al causaha-

actúan por su cuenta contienen también elementos de la tercer supuesto de casos, pues cabe entender que el causahabiente posee porque tales personas protegerán la posesión de interferencias ajenas.

${ }^{27}$ Paul. 54 ad ed. D.41,2,1,21.

${ }^{28}$ Paul. 54 ad ed. D.41,2,3,3.

${ }^{29}$ G. 2 rer. cott. D. $41,1,9,8$.

${ }^{30}$ Papinianus 23 quaest. D.41,2,46)

${ }^{31}$ En efecto, el énfasis en entregar la possessio más que la cosa se explica porque aquella coloca al possessor en la más ventajosa condición procesal de demandado (D'ORS, Á. DPR, p.196; KASER, M. Eigentum..., p. 277.), mientras que la tenencia per se no garantiza tal prerrogativa (sobre esto entablaron un debate Ulpiano y Pegaso; vid. Ulpianus 16 ad ed.D. 6,1,9). En todo caso, desplazado el procedimiento formulario por el cognitorio, el ejercicio del interdicto como mera estrategia procesal y su presupuesto -la possessio- perderían atractivo frente a la acreditación documental del tracto; Inst. 4,15,8: "De ordine et veteri exitu interdictorum supervacuum est hodie dicere: nam quotiens extra ordinem ius dicitur, qualia sunt hodie omnia iudicia, non est necesse reddi interdictum, sed perinde iudicatur sine interdictis atque si utilis actio ex causa interdicti reddita fuisset. "Véanse, además, Gai. 7 ad ed. provinc. D. 6,1,24: «Is qui destinavit rem petere animadvertere debet, an aliquo interdicto possit nancisci possessionem, quia longe commodius est ipsum possidere et adversarium ad onera petitoris compellere quam alio possidente petere.»; Inst. 4,15,4: "Et quia longe commodius est possidere potius quam petere, ideo plerumque et fere semper ingens existit contentio de ipsa possessione. Commodum autem possidendi in eo est, quod, etiamsi eius res non sit, qui possidet, si modo actor non potuerit suam esse probare, remanet suo loco possessio; propter quam causam, quum obscura sunt utriusque iura, contra petitorem iudicari solet.»-; se pone especialmente de manifiesto esta función procesal de la posesión en Paul. 33 ad ed. D. 18,1,34,4: "Rei suae emptio tunc valet, cum ab initio id agatur, ut possessionem emat, quam forte venditor habuit, et in iudicio possessionis potior esset.» 
biente $^{32}$ (longa manu, brevi manu ${ }^{33}$, ficta ${ }^{34}$, simbólica, o per constitutum possessorium) ${ }^{35}$.

\title{
1.3. Sobre la obligación del vendedor de procurar la propiedad al comprador
}

\author{
1.3.1. Notas sobre la noción romana de propiedad \\ Las fuentes romanas no indican que el vendedor estuviese obligado \\ a procurar la propiedad al comprador, sino que el vendedor parece
}

\begin{abstract}
${ }^{32}$ Ejemplos de cada una, por todos, en Fernández De BuJán, A. DPR, p. 438-439: «De forma progresiva se admitieron en época clásica y, con carácter general, en la etapa justinianea, supuestos de espiritualización de la traditio, en los que la entrega de la cosa se sustituía por actuaciones ficticias o simbólicas de entrega.»

33 KASER, M. / KNÜTEL, R. RPR, p. 104: «si un detentador adquiere la posesión de aquél por quien tiene la cosa -compra, por ejemplo, el arrendatario la cosa al arrendador- basta esta voluntad de poseer para sí (Eigenbesitzwille) comprendida en el acuerdo (Einigung) para que adquiera la condición de poseedor»; Celsus 27 D.21,2,62pr.: «Si rem quae apud te esset vendidissem tibi: quia pro tradita habetur, evictionis nomine me obligari placet.»; G. 2 rer. cott. D.41,1,9,5: «Interdum etiam sine traditione nuda voluntas domini sufficit ad rem transferendam, veluti si rem, quam commodavi aut locavi tibi aut apud te deposui, vendidero tibi: licet enim ex ea causa tibi eam non tradiderim, eo tamen, quod patior eam ex causa emptionis apud te esse, tuam efficio.»

${ }^{34}$ Miouel, Derecho Privado Romano, Marcial Pons, Madrid, 1992, p. 209: «Por lo demás hay una porción de casos, referidos a muebles e inmuebles, donde la valoración que hace la conciencia social lleva a una cierta espiritualización de la traditio.»; Paulus 54 ad ed. D. 41,2,1,21: «...non est enim corpore et tactu necesse adprehendere possessionem, sed etiam oculis et affectu argumento esse eas res, quae propter magnitudinem ponderis moveri non possunt, ut columnas, nam pro traditis eas haberi, si in re praesenti consenserint: et vina tradita videri, cum claves cellae vinariae emptori traditae fuerint.»; Celsus 23 Dig. D.41,2,18,2: "Si venditorem quod emerim deponere in mea domo iusserim, possidere me certum est, quamquam id nemo dum attigerit: aut si vicinum mihi fundum mercato venditor in mea turre demonstret vacuamque se possessionem tradere dicat, non minus possidere coepi, quam si pedem finibus intulissem; Iavolenus 5 ex post. lab. D.41,2,51: "Quarundam rerum animo possessionem apisci nos ait labeo: veluti si acervum lignorum emero et eum venditor tollere me iusserit, simul atque custodiam posuissem, traditus mihi videtur. idem iuris esse vino vendito, cum universae amphorae vini simul essent. Sobre la traditio ficta, Riccobono, S. «Traditio ficta», SZ (33), 1912, pp. 259-304.

${ }^{35}$ KASER, M. / KNÜTEL, R. RPR, p. 104: «Si, viceversa, se vende una cosa y al mismo tiempo se le arrienda al vendedor, el adquirente mantiene la posesión animo et corpore, pero sin entrega corporal, porque el enajenante ejerce ahora el poder de hecho por el adquirente como detentador; también este caso, el constitutum possessorium («Besitzkonstitut»; el nombre es influencia de Ulp. D.41,2,17,1) es familiar para los clásicos»; la construcción se encuentra ya en Celsus 23 Dig. D.41,2,18; MIQUEL, J. DPR, p. 209: «Si en la traditio brevi manu una persona que poseía nomine alieno pasa a poseerla nomine proprio, en el constituto posesorio, caso inverso, una persona que poseía nomine proprio pasa a poseerla nomine alieno.» Contemplan el constititum possessorium el art. $1462 \mathrm{CC}$ o el § 930 BGB.
\end{abstract}


obligarse a lo sumo a entregar la posesión de la cosa y garantizar al comprador su tenencia pacífica ${ }^{36}$. La cuestión, sin embargo, no está exenta de dificultades por la imprecisión del concepto romano de propiedad.

En las fuentes clásicas no aparece una definición de propiedad ${ }^{37}$. Ello se debe a la aversión de los juristas romanos clásicos hacia las definiciones de conceptos en términos absolutos ( [O]mnis definitio in iure civili periculosa est» ${ }^{38}$ ). No obstante, la falta de un término no es óbice para la existencia del concepto desde una etapa bien remota.

Existen en latín de época clásica dos términos para expresar el concepto de propiedad: dominium y proprietas. Ninguno de los dos es muy antiguo: dominium (de domare $>$ domus $>$ dominus $>$ dominium) ${ }^{39}$ aparece a finales de la república ${ }^{40}$, y proprietas (de proprium) es todavía más moderno, posiblemente de mediados del principado. Además, en su uso técnico, estos dos términos no siempre fueron exactos sinónimos ${ }^{41}$.

${ }^{36}$ Para R. Zimmerman (The Law Of Obligations..., p 278) la principal obligación del vendedor es, de hecho, la de procurar «la libre e intacta posesión en la que el comprador pueda entrar sin perturbación por parte del vendedor o de tercero».

37 Miquel, J. DPR, p. 165: «En las fuentes romanas no se encuentra una definición de propiedad. Dos motivos se suelen aducir para explicar este hecho sorprendente: 1) La aversión que los romanos sienten hacia los conceptos abstractos les hace enfocar los problemas desde el punto de vista dinámico de la acción, y ello hace que se sientan poco inclinados a definir derechos subjetivos. 2) La dificultad de encerrar en una misma definición las diversas formas de propiedad, aunque este segundo argumento parezca menos convincente.»

${ }^{38}$ Iavolenus 11 epist. D. 50,17,202.

${ }^{39}$ KASER, M. Eigentum..., p. 308; sobre la línea semántica «domus-dominus-dominium», FUENTESECA, P. «El titulus y el modus de los glosadores boloñeses. Clave interpretativa del asíndeton. Usus auctoritas (XII Tab. VI,3) y de la historia del concepto romano de la propiedad», en Estudios en homenaje al profesor Luis Diez-Picazo, t. IV, Thomson-civitas, Madrid, 2003, p. 5736.

40 KASER, ibidem: "la primera vez que aparece en fuentes jurídicas lo hace en la lex agraria de $111 \mathrm{aC}$ : "is ager locus do]mneis privatus ita, utei quoi optima lege privatus est, esto»; en fuentes no jurídicas, Cicerón, p. Caec. 20,57; FUENTESECA, P. «El titulus y el modus...», p. 5727.

${ }^{41}$ De acuerdo con KASER, M. Eigentum..., 306-312, el término proprietas se encuentra ya en la literatura antigua (muy frecuente en Vitruvio) para referirse a la cualidad de lo proprius, denotando así una relación de pertenencia (Zugehörigkeit). En tiempos clásicos se evita su utilización para referirse a la propiedad, pues aparece frecuentemente contrapuesto a dominium para referirse a la «nuda propiedad». Se habla así -G. 2 inst. D. 41,1,10,3- del "dominio de la propiedad»; Iulianus 44 Dig. D.41,1,37,5 (domino proprietatis); Paulus 9 ad plaut. D.41,1,49 (proprietatis dominium)-. Sólo en el periodo clásico tardío aparecen como equivalentes; D'ORS, Á. $D R P$, p. 185: «Proprietas ... empieza por significar la pertenencia limitada de una cosa, en especial, la del «nudo propietario», cuyo derecho está limitado por el usufructo de otra persona»; FERNÁNDEZ DE BUJÁN, A. DPR, p. 385. 
El concepto romano de propiedad, sin, embargo, es mucho más antiguo que estos dos términos. En época arcaica se afirmaba la propiedad con la expresión «meum esse», que encontramos testimoniada en el marco del enfrentamiento ritualizado de la legis actio sacramento in $\mathrm{rem}^{42}$. En esta acción, el vindicante ${ }^{43}$-lo eran, en sentido estricto, tanto demandante como demandado- no pretendería otra cosa

42 D'ORS, Á. $D P R$, p. 185: «en la fórmula oral de la vindicatio se indica la propiedad por «meum esse ex iure Quiritium»». En contra, MIQUEL, J. DPR, p. 170: «Así pues, mancipium es el primitivo nombre de propiedad. A su lado hay una perífrasis como el hanc rem meam esse aio de la legis actio sacramento in rem. Aquí, naturalmente, no hay que ver que ese «afirmo que la cosa es mía» tenga ya, sin más, la misma configuración y contenido que la moderna propiedad. De pensar así cometeríamos el mismo error que un empedernido iusnaturalista hispano, cuando con toda ingenuidad defendía que la propiedad es tan de Derecho natural que hasta el niño pequeño tiende a decir «esto es mío.»

Obviamente, la concepción de propiedad que pueda tener el romano arcaico al pronunciar tales palabras no coincidirá con el concepto moderno, pues a lo largo del tiempo las facultades correspondientes al propietario han sido objeto de numerosas limitaciones, de una parte por la necesidad de desgajar facultades económicas y propiciar la especialización en la explotación de las cosas a través de derechos limitados y, de otra, por la conveniencia de subordinar en determinadas ocasiones la propiedad privada al interés público. A nuestro juicio, tratar de encontrar un término romano para un concepto moderno responde a un planteamiento equivocado, en esto nos parece acertada la apreciación del autor. Ahora bien, sí creemos que la perífrasis ...meum esse... representa una concepción romana de propiedad, al menos la concepción de propiedad de su tiempo, posiblemente como pretensión a un aprovechamiento exclusivo de la cosa, pues en un primer momento no existe la noción de derecho limitado. Además, como veremos, los jurisconsultos normalmente se refieren a la condición de propietario con el artículo posesivo o el caso genitivo. La utilización de proprietas o dominium es más bien excepcional. Así lo señalan también los filólogos; vid. SEGURA, S. Latín, Anaya, Madrid, 1981, p. 59: «Para indicar la posesión de las cosas materiales, se emplean normalmente los verbos habere y possidere. El concepto de «propiedad» o «pertenencia» se expresa más frecuentemente en genitivo posesivo y en adjetivo posesivo».

${ }^{43}$ El criterio etimológico es decisivo: vindicatio deriva de vim-dicere, de «decir» la violencia. (IGLESIAS, Derecho Romano, p. 222). Las fórmulas persiguen la finalidad de limitar una confrontación violenta, de tal manera que si antes la violencia se ejercía [vim-agere] ahora se dice, se encierra en meras palabras (vim-dicere). Al respecto, ROYO ARPÓN, J.M. Palabras con poder, Marcial Pons, Barcelona, 1997, p. 75: «Pero para que no fuera la fuerza individual el criterio de solución de la crisis debía intervenir entonces, en plena lucha formal por la tenencia física de la cosa controvertida, una fuerza superior que desplazara la fuerza de los contendientes y posibilitara la demostración de veracidad de las afirmaciones contrapuestas por las partes en conflicto. Así, nos viene a decir GAYO, intervenía entonces el pretor, magistrado con poder sobre la ciudadanía, truncando el conato de violencia individual con la violencia institucional, política, de su orden imperativo dirigida a ambos contendientes, por lo que le bastaba con decir: "mittite ambo hominem», esto es: "dejad de ejercer violencia sobre este esclavo». 
que recuperar el exclusivo y perpetuo aprovechamiento económico de la cosa.

Aunque las fuentes disponibles son muy limitadas, parece que este concepto de propiedad arcaico no quedaba sujeto a limitación alguna, al no existir la noción de derecho real en cosa ajena (originariamente sólo existía la vindicatio rei) ni hallarse suficientemente desarrollado el poder político como para imponer limitaciones de interés público ${ }^{44}$. El aprovechamiento económico de la cosa no sería susceptible de limitación alguna, ni cualitativa (en cuanto a las facultades $)^{45}$, ni cuantitativa (en cuanto al tiempo). Por esta razón, incluso en época clásica, cuando las limitaciones efec-

${ }^{44}$ Una exposición de los derechos limitados por orden de aparición en FERNÁNDEZ DE BUJÁN, A. DPR, p. 381: «Los más antiguos derechos reales reconocidos fueron las servidumbres, en especial la de paso y la de acueducto, y la propiedad. Con posterioridad se tipificaron los derechos reales de usufructo y uso. A finales de la República comienzan ya a delinearse los derechos reales de prenda e hipoteca, por obra, en buena medida, de la jurisdicción pretoria. Ha de esperarse a la época postclásica para que se produzca la regulación definitiva de la enfiteusis y la superficie y, ya por último, la habitación, consistente en el derecho de habitar una casa, se configura en el Derecho justinianeo, como derecho real independiente del uso y del usufructo.» Sobre las limitaciones de derecho público, ibidem, pp. 388 ss.; monográficamente, PLESCIÁ, J. «The development of the exercise of the ownership right in roman law, BIDR, 1985 (88), pp.181-207.

${ }^{45} \mathrm{La}$ invocación de un derecho limitado se instrumentaría, de hecho, tomando la vindicatio rei como molde; KASER, M. Eigentum..., p. 18: «La acción para la defensa de la propiedad del camino o del paso de agua era la vindicatio, con la que el demandante afirmaba estar más legitimado que el adversario a la utilización de las demandadas funciones del dominio. Sólo con el reconocimiento de derechos independientes se separa la vindicatio servitutis de la vindicación de las cosas.» No obstante, también cabe pensar que el orden lógico y cronológico sea el inverso, esto es, que la concepción social de ius -como «derecho subjetivo»- surja como consecuencia de la generalización de un mecanismo procesal a través del cual se hace valer el interés -vindicatio/actio >ius- (sobre precedencia de lo procesal sobre lo conceptual es interesante el artículo de CASTRO SÁEZ, A. «Notas sobre un paralelismo en la creación pretoria del derecho», RIDA 2000, pp. 205 y, sobre todo, p. 219: «De este modo, el pretor, en época histórica, viene a hacer lo mismo que se fue cuajando lentamente en época protohistórica: la coagulación, en virtud de la protección manifestada por la autoridad, de derechos que sin su defensa no existen: es la defensa, la actio, lo que los actúa, lo que los pone en movimiento, lo que los hace nacer.») Con todo, si bien en la intentio de la vindicatio rei se hace referencia a la cosa (Si paret rem qua de agitur) y en la de la vindicatio servitutis se hace referencia al derecho de paso (Si paret AA ius esse ... ire agere), lo cierto es que tal distinción entre cosa y derecho (limitado) que se desprende del cotejo de las fórmulas no acaba de trasladarse -como sería de esperar- a la clausula arbitraria de la condemnatio, que sigue hablando de «ea res ... restituetur» en vez de referirse a la restitución o reconocimiento de un derecho independiente. 
tivas del ejercicio del derecho de propiedad son notables, el concepto seguiría definiéndose en torno a la potencialidad del ejercicio de tales poderes absolutos ${ }^{46}$.

$\mathrm{Al}$ margen de los referidos términos "proprietas» $\mathrm{y}$ "dominium» el concepto de propiedad se expresaba en época clásica con otros muchos giros, entre los que destacan el empleo del artículo posesivo $^{47}$, del caso genitivo ${ }^{48}$ y el de otras locuciones minoritarias, como pertinere ${ }^{49} \mathrm{O}$, incluso, in bonis esse/habere ${ }^{50}$. Esta consideración nos permite buscar el concepto de propiedad en fuentes como Modestinus 7 reg. D.41.1.52 - «em in bonis nostris habere intelligimur, quoties possidentes exceptionem, aut amittentes ad recuperandam eam actionem, habemus» o Celsus 18 Dig. D.6, 1,49,1: "Meus est, quod ex re mea superset, cuius vindicandi ius habeo». En estos textos se pone el acento en la facultad de retener o de recuperar la $\operatorname{cosa}^{51}$ porque estas facultades son el presupuesto del

${ }^{46}$ Pocos términos hay en Derecho tan felices como el de la «elasticidad» para denotar esta cualidad. Por todos, LACRUZ, J.L. Elementos de Derecho Civil, tomo III, vol. I, Dykinson, Madrid, 2000, p. 234: «El dominio, se dice, es elástico, no ya porque pueda ser despojado de algunas o muchas facultades sin dejar de ser dominio, sino porque potencialmente abarca y reclama todas las posibles influencias sobre la cosa, reabsorbiéndolas en tanto no las tenga jurídicamente otro titular».

${ }^{47}$ G. 2 rer. cott. D.41,1,3,2 -nostrum esse desinit-; G. 2 rer. cott. D. 41,1,5,1 -statim nostra esse intelligatur-idem/2 -non magis nostrae esse intelliguntur-; idem/4 -donec in conspectu nostro est-; idem/5 -nostrae esse intelligantur-idem/6 -ansares mei, et gallinae mei-G. 2 rer. cott. D.41,1,7,2 -tuam permanere- D.41,1,7,4 -eius scilicet, cuius et fuit-; idem/5: -eorum est, qui prope ripam...-; G. 2 rer. cott. D.41,1,9,3: "Hae quoque res, quae traditione nostrae fiunt, iure gentium nobis adquiruntur; nihil enim tam conveniens est naturali aequitati, quam voluntatem domini volentis rem suam in alium transfere, ratam haberi».

${ }^{48}$ G. 2 rer. cott. D.41,1,1,1/41.1.5.7 -capientium fiunt-; G. 2 rer. cott. D.41,1,7,3 -occupiantis fit-; G. 2 rer. cott. 41.1.7.13 -in vicinum fundum-.

${ }^{49}$ Papinianus 3 resp. Dig. 18.1.73.1: "Intra maceriam sepulchrorum hortis vel ceteris culturis loca pura servata, si nihil venditor nominatim excepit, ad emptorem pertinente.

${ }^{50}$ Esta locución es especialmente peligrosa, por lo que sería imprudente tomar partido sin un previo estudio, al menos, de la literatura más autorizada. Al respecto, SANSÓN, M.V. La transmisión de la propiedad..., p. 32, nota 4. De acuerdo con la autora, frente a la tesis de Bonfante -asumida después por Kaser-, se alzaría la concepción de Diòsdi, para quien in bonis esse/habere designan genéricamente la pertenencia de una cosa al patrimonio de una persona, sin especificar legalmente el título. Después, Ankum, Van Gessel-De Roo y Pool, consideran que cabe distinguir, a su vez, entre «in bonis meis esse» $\mathrm{y}$ "in bonis meum esse».

${ }_{51}$ Cfr. art. 348 II CC: «El propietario tiene acción contra el tenedor y el poseedor de la cosa para reivindicarla»; § 985 BGB: «El propietario puede exigir del poseedor la restitución de la cosa». 
ejercicio de un poder -de hecho ${ }^{52}$ - tendencialmente omnímodo ${ }^{53}$ y perpetuo ${ }^{54}$ que hoy identificamos con la propiedad.

\subsubsection{La obligación de transmitir la propiedad al comprador.}

Una vez delimitado el concepto romano de propiedad procede preguntarse si el vendedor se obligaba típicamente a transmitir la condición de propietario al comprador en la compraventa consensual clásica.

Si dejamos al margen las adquisiciones a título sucesorio, en el Derecho romano clásico la forma más usual de acceder a la condición

52 TALAMANCA, M. IDR, p. 441: «La difusa tipica della proprietà quale diritto asolutto è rappresentata dalla rei vindicatio, che assicura al titolare del diritto la materiale disponbibilitè ed il diretto controllo sulla cosa.»

${ }^{53}$ LACRUZ, J.L. Elementos de Derecho Civil..., p. 233, habla con toda precisión de la "vocación de generalidad» como atributo de la propiedad: «la propiedad comprende, in genere, en tanto no se halle gravada, todas las facultades, aplicaciones y posibilidades de la cosa no prohibidas por la ley, sin excepción: las actuales y las que puedan surgir en el futuro, sin necesidad de definirlas o caracterizarlas. Es imposible hacer una enunciación completa e individualizada de tales poderes, que varían según la época y el objeto...»; FUENTESECA, P. «El titulus y el modus...», p. 5752, trae a colación una acertada definición de Biondi: «La noción de propiedad que más se aproxima a la intuición romana es la siguiente: propiedad es la señoría jurídica, general y potencialmente absoluta, de una persona sobre una cosa corporal», MIQUEL, J. $D P R$, p. 168, se refiere a una definición de Bonfante que acentúa igualmente los dos rasgos: «la señoría más general, en acto o en potencia, sobre la cosa». A ambas definiciones puede achacárseles, no obstante, su carácter tautológico, pues incluyen en la definición el término a definir, ya que la señoría no es sino la traducción medieval de dominium. Es curioso que acierten de lleno en los adjetivos -vocación de generalidad y elasticidad- pero yerren en el sustantivo adjetivado (señoría). A mi juicio, si se hablara del «único derecho elástico con vocación de generalidad» desaparecería la redundancia.

${ }^{54}$ Sobre la perpetuidad como rasgo del dominio hay testimonios en las fuentes. Así, Constantino, preocupado por la opacidad del sistema transmisivo de su época (S. IV), alude a este elemento (Fr.V. 35.5) (traduce Amelia Castresana): «cuando con ceguera irreflexiva y descuidando la información del caso, dejando a un lado la luz de la verdad y sin pensar en la perpetuidad del dominio, disimulando y despreocupándose de todas sus omisiones se encaminan precipitadamente a que de cualquier modo y en no sé qué subterráneo se celebren prácticas... [mi cursiva]». La perpetuidad también viene limitada por la voluntad -de enajenarla- y la vida del propietario persona física, pues el derecho subjetivo -y la propiedad es el paradigmático- no es independiente de la persona. De otra opinión es LACRUZ, J.L. Elementos de derecho civil..., p. 235: «En cuanto a la perpetuidad, significa que el derecho de dominio no depende de la vida del titular ... está llamado a durar sin límite de tiempo entre las manos de los sucesivos dueños mientras siga existiendo físicamente el objeto sobre el que recae». El autor adopta la tendencia romana a equiparar la propiedad con la cosa misma. 
de propietario era a través de una cadena válida de adquisiciones basadas en una iusta causa adquirendi. ${ }^{55}$ La compraventa era la iusta causa adquiriendo paradigmática. Pero además de la existencia de una iusta causa era necesario que el transmitente tuviese poder de disposición y otorgase la posesión (lo que normalmente requería la traditio) $)^{56}$.

Si la cadena de transmisiones se rompe en algún punto (hurto, causa nula, resuelta o iniusta, o disposición sin potestas alienandi) y no ha sido reanudada por medio de una usucapión válidamente completada, los sucesivos vendedores no podrán transmitir la propiedad. Por lo tanto, la transmisión del dominio al comprador no depende sólo del vendedor, sino también de los demás auctores, desde la adquisición "originaria» ${ }^{57}$. Si en alguno de los eslabones concurriera alguno de los vicios señalados, el despojado sin su consentimiento - privado ilegítimamente ${ }^{58}$ - o perjudicado por la torpeza de la causa podría vencer al comprador con el ejercicio de la reivindicatio y privarle irrevocablemente de la cosa (téngase en cuenta el amplio concepto de furtum en Roma -por todos, G. 2.50- y el hecho de que las res furtivae no puedan usucapirse $)^{59}$. $\mathrm{Si}$, por el contrario, el tracto fue-

${ }^{55}$ Sobre la terminología que la doctrina adopta para diferenciar las causas de adquirir respecto de las demás causae volveremos más adelante, al tratar la evolución del concepto de causa; infra II.1,1,2.

56 Ya hemos señalado por qué era importante el otorgamiento de la condición de possessor; en cuanto a la potestas alienandi, vid. infra, II, 1.1.2.

${ }^{57}$ Ya desde tiempos remotos puede reconocerse la propiedad en un habere jurídicamente apuntalado en una "cadena» de causae -die Kette rechtmä iger Erwerbsvorgänge bis zurück zu einem ursprünglichen Erwerber- (vid. KASER, "Neue Studien...», p. 183).

${ }^{58}$ Cfr. art. 464 CC.

${ }^{59}$ G. 2,45/47/49-50. De hecho, para Kunkel, De Visscher y Leifer la usucapión no es sino una presunción procesal de propiedad a favor del poseedor que cumpla ciertos requisitos (tiempo y título), pero que admite prueba en contrario. Así, si la contraparte demostrara que alguno de los auctores del que alega la usucapión le hurtó a él la cosa, se le devolverá. No es, por tanto, que la usucapión venga excepcionada por el carácter furtivo de la cosa (res inhabilis), sino que la demostración del hurto por parte del demandado enerva la presunción de propiedad que la usucapión representa para el demandante. Igualmente con los papeles invertidos. La misma interpretación defiende Kaser para la regla decemviral usus auctoritas fundi biennium est, ceterarum rerum omnium annus est usus (Tabla VI.3 ${ }^{\mathrm{a}}$ ). Un análisis exhaustivo en KASER, M. Eigentum..., p. 86 ff., de lo que cabe destacar lo siguiente (p.87): «El poseedor no ostentaría con ello un nuevo derecho adicional, sino que sólo se le facilita notablemente la defensa de su posesión. El paralelismo con la «rechte Gewere» del Derecho alemán es evidente. La negativa arcaica (altrömische Verschweigung) [a apelar al auctor (laudatio auctoris denuntiatio)] bien pudo llamarse ya "usucapio», porque garantizaría al poseedor la adquisición de una mejor posición jurídica.» Por esto extraña que a renglón seguido acepte la explicación tradicional de la usucapio: «Frente a esto hay 
ra correcto, es obvio que nunca aparecería el verus dominus; tal sería precisamente la condición del comprador, último eslabón de una cadena válida.

La inevitable incertidumbre acerca de quién sea el verus dominus $^{60}$ tiene como contrapeso la brevedad de los plazos de usucapión aplicables en el derecho romano clásico (un año para los muebles y dos para los inmuebles). Ello lleva a los juristas romanos clásicos a relevar al vendedor de responder por la ajenidad cuando se observe un vicio en el tracto sucesivo en tanto el comprador no se vea privado de la cosa por la evicción, pues debieron de considerar que no tiene sentido que un comprador que puede adquirir en breve el dominio por vía de usucapión y que no ha sido molestado por el verus dominus pueda demandar a un vendedor por incumplimiento contractual. Bastará, pues, que el vendedor garantice al comprador el uso y disfrute tendencialmente perpetuo de la cosa, lo cual, en definitiva, viene a equivaler de facto al disfrute de las facultades de la propiedad desde el día mismo en el que se produjo la traditio ${ }^{61}$.

Por otro lado, no puede reprocharse a un vendedor el hecho de no haber transmitido la propiedad al comprador si este efecto jurídico no depende de él, sino que es una consecuencia de la regla nemo

una usucapión (Ersitzung) verdera que procura al poseedor una propiedad que antes todavía no tenía, y que se manifiesta sólo tras la aparición de una propiedad absoluta.» Parece que la razón es que la explicación oficial de la usucapio casa mejor con su nítida distinción entre una propiedad relativa para el procedimiento de las legis actiones y una absoluta tras la inversión de la carga de la prueba en el procedimiento formulario. MIQUEL, J. DPR, p. 174, también se refiere a esta función procesal de la usucapión: «Respecto a la carga de la prueba, la postura del demandado poseedor, puramente pasiva, es evidentemente muy favorable. Es el demandante el que sufrirá las consecuencias de la falta de prueba. La usucapión venía aquí a simplificar la prueba del demandante y el peso de la misma recaería en haber tenido una possessio ex iusta causa.»

60 Se trasluce tal aleatoriedad en un relevante pasaje de Ulpianus 32 ad ed. D.19,1,11,2: «...si quidem dominus fuit venditor, facit et emptorem dominum, si non fuit, tantum evictionis nomine venditorem obligat...»; ZIMMERMAN, R. The Law of Obligations, p. 279: «De ahí que uno sólo pudiera esperar del vendedor que hiciera todo lo que estuviera en su mano para transferir la propiedad.»

${ }^{61}$ Idem, p. 278: «Además, tenía que mantener al comprador en la incontrovertida posesión y disfrute de la cosa, hacerle merecedor de su habere licere o, como algunas fuentes señalan más exhaustivamente, de su uti fruti habere possidereque licere»; De acuerdo con TALAMANCA, M. IDR, p. 580, la función socio-económica de la compraventa es «lo scambio tra la definitiva disponibilità della cosa ed il suo valore espresso in denaro.» El hecho de que el autor hable de la definitiva «disponibilidad» $\mathrm{y}$ no de la «disposición» encierra el matiz de la potencialidad del ejercicio de tal derecho -el de tenerla consigo- (la usa en este sentido en p. 586). 
plus iuris ad alium transferre potest quam ipse habet ${ }^{62}$. Naturalmente, se exceptúa el caso de que el vendedor conscientemente vendiese una cosa ajena ${ }^{63}$. Aunque su conducta no sea reprochable, el vendedor responde por evicción al considerar el Derecho romano clásico que es más justo imponer el riesgo de la titularidad sobre la cosa vendida al vendedor que al comprador. De hecho, el vendedor puede prestar una garantía especial por ese riesgo mediante la stipulatio duplae $^{64} \mathrm{o}$ bien puede trasladarse el riesgo al comprador mediante el pactum de non praestanda evictione ${ }^{65}$ a cambio, normalmente, del pago de un menor precio en atención a tal circunstancia. Al ser un traslado convencional del riesgo, el vendedor no evita responder si conoce la ajenidad de lo que vende ${ }^{66}$.

La responsabilidad por evicción -sea por pacto o por inherencia al contrato de compraventa- es el presupuesto necesario para entender que el vendedor se obliga a transmitir la propiedad al comprador, pues tal obligación se traduce en hacer que su causahabiente prevalezca en un juicio vindicatorio -obligación de resultado ${ }^{67}$ - y al ven-

${ }^{62}$ Sobre el origen del brocardo, SANSÓN, M.V. La transmisión de la propiedad, Marcial Pons, Barcelona, 1998, p. 7, nota 1, con las principales referencias bibliográficas.

${ }_{63}$ Ulpianus 32 ad ed. D.19,1,11,15; también Juliano, seguido por Ulpianus 32 ad ed. D.19,1,11,16.

${ }^{64}$ También el triplum o cuadruplum: Paulus 2 ad ed. aedil. curul. D.21,2,56,pr.

${ }^{65}$ BURDESE, A. DPR, p. 458: "sul finere dell'età classica si ammette che, con apposito pactum de non praestanda evictione ..., il venditore si possa esimere dall'obbligo di garanzia evizionale ormai divenuto conseguenza naturale del contratto di compravendita.»; MOHINO, A. Pactos en el contrato de compraventa en interés del vendedor, Dykinson, Madrid, 2006, pp. 322 ss., basándose principalmente en Ulp. 32 ad. ed. D. $19,1,11,18$.

${ }_{66}$ Juliano, seguido por Ulpianus 32 ad ed. D.19.11.1.18; CALONGE, A. Evicción. Historia del concepto y análisis de su contenido en el Derecho romano clásico, Universidad de Salamanca, 1968, p. 118, basándose en Pomponius 9 ad sab. D. 19,1,6,9 y D. $19,1,11,15$; cfr. arts. 1102/1476 CC.

${ }^{67}$ Es menester precisar el concepto de obligación, para lo que hallamos en las fuentes mayor fortuna. MIQUEL, J. DRP, p. 257 ss., trae a colación la definición de Florentino -jurista del S. II dC.- (Inst. 3,13pr.): «obligatio est iuris vinculum, quo necessitate adstringimur alicuius solvendae rei secundum nostrae civitatis iura». De este y otro pasaje (Paulus 2 inst. D. 44,7,3pr.: «Obligationum substantia non in eo consistit, ut aliquod corpus nostrum aut servitutem nostram faciat, sed ut alium nobis obstringat ad dandum aliquid vel faciendum vel praestandum») se extrae que la obligación -de ob-ligare=atar alrededor- (p. 257) es un vínculo jurídico (los modernos prefieren hablar de «relación») por el que alguien viene compelido a un dare, facere, praestare. En sentido moderno, la responsabilidad es la consecuencia del incumplimiento de la obligación -construcción de Brinz: Schuld y Haftung como inescindibles elementos de la relación obligatoria- (p. 259). No obstante, para un romano, el mismo término de obligatio equivale a la moderna concepción de responsabilidad -de ahí que también se 
dedor sólo se le puede considerar obligado si pacta responder por la evictio o así se deduce del régimen de la compraventa. Por otra parte, el hecho de no haber procurado la propiedad es condición necesaria pero no suficiente para fundar su responsabilidad ${ }^{68}$, pues el vendedor también puede liberarse si su causahabiente (qui causam habet) deviene propietario por otros medios, lo cual ocurre en las siguientes circunstancias: i) cuando el comprador usucape ${ }^{69}$, o ii) cuando opera una convalidación sobrevenida del tracto, es decir, cuando el comprador deviene dominus por otra causa adquirendi diferente -y posterior- de la venta que celebró con su vendedor ${ }^{70}$.

consideren obligadas las cosas dadas en prenda-. Pues bien, el hecho de que el vendedor quede obligado por el duplum ante la pérdida del juicio vindicatorio de su causahabiente -porque tenía mala causa (p.ej, Ulpianus 2 ad ed. aedil. curul. D.21,2,55)equivale en cierta manera a decir que se obliga a procurarle la propiedad, pues responde de que la causa que le dio no le haya hecho prevalecer en un juicio vindicatorio. La cuestión está enmarañada porque se mezcla el plano procesal con el sustantivo. Se dice que el romano no se obliga por el contrato de compraventa a transmitir la propiedad, sino a responder cuando vencen a su comprador, pero esto último no es sino la manifestación procesal de lo primero. Si el hecho de que el accipiens tenga la certeza teórica de que no le han hecho propietario no funda todavía la responsabilidad de su vendedor -de su auctor- no es porque éste no venga obligado a procurar la propiedad, sino porque para hacer responder al vendedor tal sospecha (o incluso certeza) se tiene que articular procesalmente. Dado que no existe en Roma una acción declarativa del dominio, la mala causa del accipiens -y la correspondiente responsabilidad de su auctor - sólo saldrá a relucir en un juicio vindicatorio. Por otra parte, si el vendedor no se obligara a transmitir la propiedad, sería muy difícil de explicar que la declaración de no querer transmitir la propiedad sea incompatible con el contrato de venta-Labeo 5 post. a iav. epit. D.18,1,80,3, famoso fragmento sobre el que volveremos al exponer los textos sobre los que se construye el pacto de reserva del dominio, también citado por D'ORS, Á. DPR, p. 546, nota 2-. A contrario, entendemos que si no estipula ni el duplum ni el simplum o se pacta la non praestanda evictione cuando tales estipulaciones quedan embebidas en la actio empti, no cabe entender que se obligue a nada.

${ }^{68}$ ZIMMERMAN, R. The Law of Obligations, p. 280: «cualquier reclamación por daños está basada en última instancia en el hecho de que un tercero -en vez del comprador- es el dueño de la cosa. De ello sólo habrá certeza una vez que el tercero haya prosperado con el ejercicio de su acción contra el comprador».

${ }_{69}$ A lo que cabe formular la importante apreciación de que una res furtiva no es susceptible de usucapio, por lo que su aplicación es muy restringida; G. 2,50: «Unde in rebus mobilibus non facile procedir, ut bonae fidei possessori usucapio competat, quia qui alienam rem vendidit et tradidit, furtum committit; idemque accidit etiam, si ex alia causa tradatur.». Sobre esta y otras limitaciones, SANSÓN, M.V. La transmisión de la propiedad, p. 34.

${ }^{70}$ Tal ocurre, por ejemplo, en el caso descrito en Ulpianus 29 ad sab. D. 21,2,21pr. (ver nota 11), que responde a la siguiente estructura: Ticio hurta a Cayo un buey que vende a Sempronio y éste después deviene heredero de Cayo; D'ORS, Á. DPR, p. 494, nota 2: «El hecho de no haber adquirido la propiedad a causa de la entrega del vendedor no justifica la reclamación del comprador en Derecho clásico, pero sí en el justinianeo». 
En conclusión, entendemos que no puede decirse categóricamente si el vendedor está o no en todo caso obligado a hacer propietario al comprador, pues -definiendo la obligación como reverso de la responsabilidad-sólo podemos decir que se obliga a hacerle propietario si se prevé su responsabilidad en caso de no hacerlo, algo que se manifiesta a posteriori cuando el causahabiente queda evictus -vencido- en un juicio vindicatorio. Ahora bien, es posible que exista la certeza de que un vendedor no haya hecho propietario a su comprador y sin embargo no responda, pues el presupuesto de su responsabilidad es la evicción efectiva.

\subsection{El pago del precio y la transmisión de la propiedad}

Otra cuestión muy polémica que reviste una gran importancia para tratar el tema de la reserva del dominio: el problema de si el comprador debe haber pagado el precio para poder adquirir la propiedad sobre la cosa vendida.

La necesidad de haber pagado el precio para adquirir la propiedad sobre el bien vendido debió de ser lo más frecuente en el Derecho romano $\operatorname{arcaico}^{71}$ o vulgar ${ }^{72}$, caracterizados por el trueque. En cambio, no es necesario en el momento de mayor esplendor de la jurisprudencia romana, en que los efectos obligacionales del contrato de

${ }^{71}$ Tabla VII, 11 : «Venditae - et traditae (res) non aliter emptori adquiruntur, quam si is venditori pretium solverit vel alio modo satisfecerit, veluti expromissore aut pignore dato ; quod cavetur-lege XII tab. (Inst., 2, 1, 41 ; Cf. Pomp., ad Q. Muc., D., 18, 1, 19).

72 KASER, M. Compraventa y transmisión de la propiedad en el Derecho Romano y en la dogmática moderna, publicaciones de los seminarios de la facultad de Derecho de la universidad de Valladolid, (traducción de J. MIQUEL), 1962, p. 24: «...Pero con el paso a la época posclásica se produce un cambio muy profundo. Tras el fin de la jurisprudencia clásica, se enseñorea de la parte occidental del Imperio romano el Derecho vulgar, esto es, un Derecho que, si bien es todavía romano, desciende a bajo nivel, después de la pérdida de la cultura romana. Tras la desaparición de los grandes maestros, queda tan sólo un núcleo de profesores de Derecho y prácticos con poca capacidad y formación. El Derecho romano se torna tosco en sus manos, y se tergiversa notablemente. Este Derecho vulgar vuelve, de nuevo, al estadio de la compraventa al contado. La mancipatio y la in iure cesio caen en desuso, y la traditio pasa también a segundo plano. Ahora, lo decisivo es la compraventa que se efectúa inmediatamente transmitiendo así la propiedad. Asimismo la donación, la constitución de la dote, bastan para transmitir la propiedad, con tal de que la cosa se entregue simultáneamente. Con ello se sacrificó la distinción, cuidadosamente elaborada por los romanos, entre negocio causal y entrega, confundiéndose el negocio obligatorio y el negocio real, análogamente a como sucedía en la época primitiva con la mancipatio, a la que hemos caracterizado también de compraventa al contado... Además, el requisito del pago del precio va adquiriendo cada vez más relieve para la adquisición de la propiedad por compraventa, relegando a la traditio a un segundo plano.» 
compraventa y los reales de la traditio rei ex (iusta) causa adquirendi se encuentran claramente delimitados ${ }^{73}$.

Esto no obstante, han habido voces que han defendido que, en Derecho romano clásico, el pago del precio se concebía como requisito esencial para que el comprador pudiese adquirir la propiedad sobre la cosa vendida. Si esta tesis fuese cierta, el derecho romano clásico habría previsto una reserva del dominio implícita en cualquier contrato de compraventa.

El apoyo textual básico de esta tesis es Inst. II,1,4174, donde Justiniano, remontándose a las XII Tablas (Tabla VII.11), menciona que la propiedad de la cosa no se transmite hasta el pago del precio.

Inst. II. 1,41: Venditae vero et traditae non aliter emptori adquiruntur, quam si is venditori pretium solverit vel alio modo ei satisfecerit, veluti expromissore aut pignore dato. quod cavetur quidem etiam lege duodecim tabularum: tamen recte dicitur et iure gentium, id est iure naturali, ${ }^{75}$ id effici. sed et si is qui vendidit fidem emptoris secutus fuerit, dicendum est, statim rem emptoris fieri. ${ }^{76}$

Si se compara Inst. II,1,41 con el precedente histórico al que Justiniano hace referencia se aprecia una diferencia sustancial: la comisión tribonianea reproduce literalmente el texto de la mencionada tabla (fianza o prenda=pago ${ }^{77}$ ), pero añade un último inciso

73 TALAMANCA, M. IDR, p. 582: «La consensualità e l'obbligatorietà sono caratteristiche peculiari dell'esperienza romana rispeto agli altri ordinamenti dell'antichità e del periodo classico rispetto a quello arcaico ed al tardo-antico. La compraventita consensuale e obbligatoria risale, con tutta probabilità, al III sec. a.C., e trova la sua origine nella iurisdictio peregrina»; idem, p. 583: "Gaio [3.139] rileva esplicitamente che tale pagamento è irrelevante per la produzione degli effectti dell'emptio-venditio»; DE LOS MOZOS, J.L. "Crisis del principio de abstracción y presupuestos romanistas de la adquisición del dominio en el Derecho español», ADC 1972, p. 1042.

${ }^{74}$ Así, U. ÁLVAREZ SUÁREZ (El problema de la causa en la tradición, Real Academia de Jurisprudencia y Legislación, Madrid, 1945, p. 38) da por hecho que para la transmisión del propiedad -en el Derecho clásico- es necesario el pago del precio, basándose precisamente en este famoso fragmento de los Instituta.

${ }^{75}$ Veamos qué dice el Derecho de gentes en el pasaje anterior: Inst. II, I, 40: «Per traditionem quoque iure naturali res nobis acquiruntur; nihil enim tam conveniens est naturali aequitati, quam voluntatem domini, volentis rem suam in alium transferre, ratam haberi: et ideo, cuiuscunque generis sit corporalis res, tradi potest, et a dominio tradita alienatur».

${ }^{76}$ Este último inciso -alineado con la opinio de Pomponio- no se encuentra en la Ley de las XII Tablas.

${ }^{77}$ En un sentido similar, G. 28 ad ed. provinc. D.18,1,53: "Ut res emptoris fiat, nihil interest, utrum solutum sit pretium an eo nomine fideiussor datus sit. quod autem de fideiussore diximus, plenius acceptum est, qualibet ratione si venditori de pretio satisfactum est, veluti expromissore aut pignore dato, proinde sit, ac si pretium solutum esset.» 
introducido con una conjunción adversativa que altera completamente el sentido de la norma: la cosa se hace inmediatamente del comprador (statim rem emptoris fieri) si el vendedor confiara en él ( $s i$ fidem emptoris secutus fuerit) ${ }^{78}$. Esto sólo se explica si se entiende que Justiniano se quiso desmarcar explícitamente de la necesidad arcaica de pagar el precio para adquirir la cosa. Encontramos un caso similar en un texto de Pomponio:

Pomponius 31 ad q. muc. D. 18.1.19: "Quod vendidi non aliter fit accipientis, quam si aut pretium nobis solutum sit aut satis eo nomine factum vel etiam fidem habuerimus emptori sine ulla satisfactione. ${ }^{79}$

Conviene salvar las distancias -mil años- entre una disposición de las XII Tablas y una de los Instituta. Es muy posible que en la quinta centuria a.C. el pago fuera necesario como presupuesto de la entrega (trueque) porque pago y entrega se concebían como algo simultáneo y no porque, una vez hecha la entrega, el pago fuera el presupuesto de la transmisión de la propiedad ${ }^{80}$.

Algunos autores han considerado que en Derecho clásico se habría mantenido este efecto del contrato con carácter «dispositivo», de modo que las partes habrían podido pactar expresamente que el comprador no adquiriese la propiedad de la cosa vendida hasta que se hubiese pagado el precio. Este sería el pactum reservati dominii clásico, que no conculcaría los principios básicos del derecho romano al no modificar los rasgos del contrato de compraventa, sino sólo su consumación, esto es, la transmisión de la propiedad. ${ }^{81}$

${ }^{78}$ ZIMMERMAN, R. The Law of Obligations, p. 274, apunta que R. FEENSTRA («Fidem emptoris sequi», Studi in onore di Ugo Enrico Paoli (1955), Florencia, pp. 273 ss.) demostró que el sentido de la cláusula equivale a «una tácita confianza en la fe del comprador».

79 "Lo que he vendido únicamente se hace del que lo recibe si nos ha sido pagado el precio o se nos ha dado fianza de éste, o incluso nos hemos fiado del comprador sin garantía alguna»

80 SANDMANN, E. Zur Geschichte des Eigentumsvorbehalts in Deutschland, Marburg, 1972, p.3, 10-11. Sobre la obsolescencia de la necesidad de pago o garantía, ZIMMERMAN, R. The Law of Obligations, p. 273: «la regla devino más o menos superflua en la siguiente frase, pues allí se decía que bastaba que el vendedor «ponga su confianza en el vendedor (puts his trust in the buyer)»; para E. LEVY (West Roman Vulgar Law. The Law of Property, American philosophical society, Philadelphia, 1951, p. 150) «la necesidad de pago que Justiniano, guiado aquí por su inclinación arcaica, toma de las doce tablas en vez de los usos de su época devino ilusoria tan pronto salió de la pluma».

${ }^{81}$ CANDIL, F. Pactum reservati dominii, Centro de Estudios Históricos, Madrid, 1915 , p. 63, entiende que es posible suspender convencionalmente el efecto transmisivo de la traditio ex iusta causa: «En Derecho romano y con aplicación especial 
A nuestro juicio, la afirmación de que un inciso del fragmento de un pasaje de los Instituta es dispositivo -presumimos que todo lo anterior ha de considerarse imperativo- despierta el máximo recelo. No sólo por el hecho formal de que el emperador Justiniano otorgue a sus Instituciones en nombre de nuestro señor Jesucristo «la plenísima fuerza de Constituciones nuestras» (de hecho, las mandó escribir para un conocimiento sólido y directo de los «rudimentos de las leyes», basándose fundamentalmente en las enseñanzas de «nuestro Gayo»), sino porque tal pasaje en particular versa precisamente sobre la adquisición de las cosas, lo más imperativo por antonomasia.

Al margen de otras consideraciones, nos parece que CANDIL -principal importador en nuestro país de la doctrina alemana moderna de la

a la compraventa, el momento de consumación, aunque sometido a reglas, deja margen a la voluntad de las partes, para hacer variaciones que respondan a conveniencias dignas de respeto y que no violan ni la lógica, ni el orden público, ni la ley, ni en general terceros intereses ... La consumación es una consecuencia natural de toda relación jurídica, pero no es ni puede ser esencial en el sentido de no modificable, y esto es lo que pretende el pactum reservati dominii, no modificar la perfección, sino deferir la consumación del contrato de compraventa. ¿No sería un ataque a la libertad de las partes -dice Tendi- limitar arbitrariamente la facultad de éstas al declarar nula una condición que suspende la transmisión de la propiedad? Si todas las legislaciones permiten hacer depender totalmente el contrato, su existencia íntegra, de un hecho futuro e incierto, con más fundamento se permitirá suspender uno solo de sus efectos.»

Este último argumento, que podría parecer convincente (quien puede lo más, puede lo menos), resulta en el fondo muy engañoso. Obviamente, la celebración del contrato de compraventa depende de la entera voluntad de las partes, pero una vez celebrado han de someterse a sus reglas imperativas. En cuanto a la transmisión de la propiedad como un efecto del contrato, ha de precisarse que se trata de un efecto mediato de un contrato. Entre el contrato y la transmisión de la propiedad media la entrega -además, de la possessio-, que es lo que da lugar (y no siempre) a una suerte de "transmisión». Tal efecto "transmisivo» de la tradición no se puede condicionar, pues la consolidación de la propiedad en el comprador depende de la corrección del tracto de causas, algo que escapa totalmente a la voluntad de las partes, amén de que los efectos procesales de la possessio -que será lo que normalmente consolide la posición del comprador- están igualmente desconectados y discurren por sus propios cauces.

Sí puede condicionarse la exigibilidad de las prestaciones que derivan de un contrato, con lo que se estaría condicionando mediatamente la propia adquisición del dominio. Lo que es ajeno a las reglas del Derecho romano clásico -y de los ordenamientos latinos que beben de ellas, al menos en cuanto a los bienes «no registrados» se refiere- es que se verifique la entrega de la cosa basada en una (iusta) causa adquirendi, esto es, en aquellos "ciertos contratos» de los que habla el art. 609 CC, y se pacte que la propiedad no se haya «transmitido", pues la reglas por las que se asignan derechos con vocación de oponibilidad -y la propiedad es el paradigmático- no son dispositivas. Hay intereses de terceros en juego. 
reserva del dominio $-^{82}$ hace una lectura ciertamente sesgada del segundo capítulo del libro primero de los Instituta, posiblemente para erigir así sobre textos romanos el pactum reservati dominii que con tanto empeño trata de legitimar. No obstante, si ya es contradictorio tal fragmento con el que le antecede ${ }^{83} \mathrm{y}$ con los que le proceden ${ }^{84}$, el hecho de no hallar en el título de la compraventa (Inst. 3.23) una regulación coherente con su hipótesis debilita notablemente sus argumentos ${ }^{85}$.

A mayor abundamiento, una vez visto que las fuentes abonan mayoritariamente la independencia entre pago del precio y transmisión de propiedad, desde una perspectiva procesal no se concibe cómo podría vencer el vendedor con el ejercicio de la reivindicatio si otorgó una causa del dominio a favor de su comprador. El impago no destruye per se una causa perfeccionada por el mero consentimiento, de ahí que para la recuperación de la cosa tuviera que instar el vendedor la resolución del contrato por medio de la lex commissoria, que es precisamente el remedio ordinario que se impondrá para cumplir esta función garantista perseguida por el vendedor ${ }^{86}$.

${ }^{82}$ La construcción dogmática de la reserva del dominio en Alemania no es extrapolable al ordenamiento español, pues de acuerdo con el § 449 BGB se condicionan los efectos del negocio abstracto de transmisión (Verfügungsgeschäft), mientras en el ordenamiento español, a falta de tal segundo negocio y siendo perfecto el obligacional -la compraventa- el mencionado autor pretende que se condicionen los efectos de la entrega, al que por las razones señaladas en la nota 79 es inconcebible.

${ }^{83}$ Inst. II,1,40: «Per traditionem quoque iure naturali res nobis acquiruntur; nihil enim tam conveniens est naturali aequitati, quam voluntatem domini, volentis rem suam in alium transferre, ratam haberi: et ideo, cuiuscunque generis sit corporalis res, tradit potest, et a domino tradita alienatur». Savigny vería en II,1,41, de hecho, el fundamento de la transmisión abstracta. Sobre esta cuestión, DE LOS MOZOS, J.L. "Crisis del principio de abstracción...», p. 1033, nota 28.

${ }^{84}$ Tampoco hay mención alguna al pago del precio en Inst. II,I,42 -traditio voluntate dominii-; idem/44 -traditio brevi manu-; idem/45 -traditio clavium-.

${ }^{85}$ De acuerdo con E. LEVY (West roman vulgar law, p. 149) Inst. 3.23 está basado en G. 3,39 -añadiendo "sine scriptura consistunt»-, donde no se exige el pago -ni la escritura, ni el arra- para que las partes se obliguen. $\mathrm{Si}$ «emptio et venditio contrahitur» sólo falta la entrega (Inst. 3, 23, 3: «qui nondum rem emtori tradidit, adhuc ipse dominus est.» Por otra parte, a juzgar por las Constituciones posclásicas que versan sobre una compraventa con precio aplazado es indiscutible que el comprador se hace propietario por la traditio ex iusta causa adquirendi; p.ej., C.4,38,8/9, respectivamente: «Si non donationis causa, sed vere vineas distraxisti nec pretium numeratum est, actio tibi pretii, non eorum quae dedisti repetitio competit. * diocl. et maxim. aa. et cc. herodi et diogeni. * <a 294 d. xvii k. april. cc. conss «.... placito autem pretio non numerato, sed solum tradita possessione istiusmodi contractus non habetur irritus, nec idcirco is qui comparavit minus recte possidet, quod soluta summa quam dari convenerat negatur.. * diocl. et maxim. aa. et cc. severo mil. * <a 294 d. viii k. april. sirmi cc. conss. >»

${ }^{86}$ Aún hoy el BGB exige la resolución del contrato como conditio sine qua non de la recuperación de la cosa vendida con reserva de dominio; cfr. § 449 II. 


\subsection{Las consecuencias del impago del precio}

Por la mentada independencia entre los efectos de la entrega ex iusta causa y los efectos obligacionales de la compraventa, el vendedor a quien no le haya sido pagado el precio se encuentra en una situación sumamente delicada ante la insolvencia o renuencia al pago de su comprador, pues sólo dispone de acción para reclamar el precio -actio venditi ${ }^{87}$ (actio pretii en los albores del derecho posclásico)-, en ningún caso se le permite el ejercicio de la reivindicatio. Tal indefensión es especialmente acusada en derecho romano, que -hasta la introducción de la lex commisoria ${ }^{88}$ - desconoce el mecanismo de la resolución del contrato por el mero incumplimiento.

\subsection{Mecanismos alternativos para proteger al vendedor frente al impago}

\subsubsection{Entrega por causa no encaminada a la transmisión del dominio}

Dado que la entrega basada en una causa adquirendi/dominii siempre lleva aparejado el efecto de la transmisión dominical -supuesta la propiedad del tradens-, el efecto práctico de no procurar la propiedad hasta el pago del precio se obtenía mediante una entrega basada en una de las causas que no estuvieran enderezadas a la transmisión del dominio. Las causae que primero acuden a la mente son el arrendamiento y el precario. De esta forma, a pesar de entregar la cosa al accipiens, la propiedad permanecía en el tradens -de nuevo, si modo eius dominus fuerit-, quien supuestamente prevalecería con la reivindicatio para recuperar la cosa en caso de impago. El estudio de los siguientes fragmentos es especialmente relevante porque son los que frecuentemente se aducen para justificar la existencia del pactum reservati dominii en Roma. ${ }^{89}$

${ }^{87}$ KASER, M./KNÜTEL, R. RPR, p. 208; Von GLÜCK, C.F. Ausführliche Erläuterung..., p. 221, señala que la acción está dirigida fundamentalmente a exigir el pago del precio, incluso cuando el vendedor hubiera pensado erróneamente que se había pagado por compensación. La recuperación de la cosa sólo podía interesarse en los casos en que el comprador hubiera tomado posesión de más de lo que le hubiera correspondido y cuando se resolviera el contrato, en cuyo caso podría optar -en el Derecho tardío- entre la actio venditi y la praescriptis verbis, siendo la cuestión discutida en cuanto a la etapa anterior (p.224).

${ }^{88}$ Sobre la lex commissoria, Infra, I, 1.6.2.

${ }^{89}$ CANDIL, F. Pactum reservati dominii, pp. 58 y 59, se basa en ciertos pasajes del Digesto que, aunque en ningún momento se refieren expresamente al pactum reservati dominii, según el autor hacen referencia inequívoca a él (D.19.1; D.39.2; D.43,26; D.4,54; D.18,6; D.19,2). 
Iavolenus 7 ex cass. D.18,6,17: Servi emptor si eum conductum rogavit, donec pretium solveret, nihil per eum servum adquirere poterit, quoniam non videtur traditus is, cuius possessio per locationem retinetur a venditore periculum eius servi ad emptorem pertinet, quod tamen sine dolo venditoris intervenerit.

En el caso descrito se celebran dos contratos simultáneamente: una compraventa y un arrendamiento cuya finalidad es permitir que el comprador-arrendatario pueda disfrutar de la cosa sin haber pagado totalmente el precio ${ }^{90}$. A pesar de que no se diga expresamente, hay que entender que el vendedor sigue siendo el propietario, pues no ha hecho poseedor a su causahabiente, quien, sin embargo, tiene una causa dominii válida.

Si bien es muy probable que mediante estas combinaciones de causas se obtuviera el efecto garantista perseguido por el vendedor, lo cierto es que, como veremos, de ninguno de los fragmentos se desprende una explicación de esta supuesta postergación en la adquisición del dominio.

Lo que sí resulta claro es que este mecanismo de la combinación de causas no resulta equiparable a la reserva de dominio en su concepción moderna (venta y entrega con transmisión del dominio suspensivamente condicionada al pago del precio), pues aquí el esclavo se ha dado en arrendamiento (eum conductum) y en la versión moderna del pactum reservati dominii sólo hay una venta.

Paulus 34 ad ed. D. 19,2,20,2: "Interdum locator non obligatur, conductor obligatur, veluti cum emptor fundum conducit, donec pretium ei solvat» ${ }^{91}$.

${ }^{90}$ Sobre este fragmento, en una réplica a la interpretación de Daube, J.A.C. THOMAS, («Tenancy by purchaser», Iura 1959 (10), p. 105) considera que la intención principal de las partes es la de celebrar una venta y la adición de un arrendamiento cumple la función cautelar de hacer que permanezca la propiedad en el vendedor. Si bien el autor no alude expresamente a un false lease, sí que dice que la merced arrendaticia se fija en función del precio y del tiempo. En cualquier caso, no le parece que sea conforme a la buena fe que el comprador siga vinculado por el arrendamiento tras el pago anticipado del precio. Alude, de hecho, al lease E. SANDMANN (Zur Geschichte des Eigentumsvorbehalts..., p. 8), quien entiende que a través de la venta y dación en arrendamiento consigue el vendedor el efecto de seguir como propietario hasta el pago del precio. Si bien el autor no explica exactamente cuándo pasa la propiedad y en virtud de qué argumento jurídico sí tiene claro que esta combinación de contratos no equivale al pactum reservati dominii tal y como se concibió en el ius commune -así lo ve también F. Wieacker- porque durante la Edad Media se adopta la explicación del condicionamiento de la traditio.

${ }^{91}$ Sobre este pasaje, KASER, M. / KNÜTEL, R. RPR, p. 207: «El precio puede pagarse a plazos. La venta a plazos se perfeccionaba normalmente de forma que el 
En este texto de Paulo se reproduce el mismo esquema que en el fragmento anterior: venta con arrendamiento hasta que se pague el precio. Lo específico del texto es que fija las obligaciones y acciones de cada parte: el arrendatario queda obligado al pago de la renta y a la devolución de la cosa al fin del período contractual, pero el arrendador sólo se obliga como vendedor. Por tanto, no le corresponde el riesgo por pérdida de la cosa, ya que la obligación de mantener al comprador-arrendatario en la pacífica posesión de la cosa le corresponde en virtud de la compraventa.

Iavolenus 11 epist. D.19,2,21: Cum venderem fundum, convenit, ut, donec pecunia omnis persolveretur, certa mercede emptor fundum conductum haberet: an soluta pecunia merces accepta fieri debeat? respondit: bona fides exigit, ut quod convenit fiat: sed non amplius praestat is venditori, quam pro portione eius temporis, quo pecunia numerata non esset ${ }^{92}$.

comprador tomara la cosa hasta el completo pago del precio como mero arrendatario, comodatario o precarista, esto es, de momento no por causa de compra (pro emptore), con lo que no adquiría una posición autónoma. La compra permanecía con esta combinación con la locatio conductio como el contrato prevalente, con las importantes consecuencia a efectos de transmisión de riesgo y responsabilidad de que el vendedor sólo se obliga como vendedor y el comprador, por el contrario, venía obligado como arrendatario o comodatario (Paul. D.19,2,20,2: locator non obligatur, conductor obligatur; D.19,2,22 pr.)». De acuerdo con D. DAUBE («Tenancy of purchaser and lex commissoria», RIDA 1958 (5), p. 433), la acción para exigir el pago del precio es la actio venditi, pero si la venta se anula, el vendedor habrá de cumplir con sus obligaciones de arrendador. El autor ve en este fragmento el antecedente de D. 19,2,22pr.: Igualmente (Item...) si haciéndose la cosa incomprada -por la lex commissoria-, entonces (tunc) tendrá la acción ex conducto. Más recientemente, sobre la serie de fragmentos D. 19,2,20,2; D. 19,2,22pr.; D.19,2,21, véase MOHINO, A. «A propósito de D.19.2.20.2 en relación con D.19.2.22.pr.», RIDA (45), 1998, pp. 413-428. De acuerdo con la autora, mientras el primero establece la prevalencia de la venta sobre el arrendamiento y asigna las acciones correspondientes a cada parte (locator non obligatur, conductor obligatur), el segundo y el tercero contemplan los efectos del incumplimiento (exigencia del pago de rentas con la actio locati tras la resolución de la compraventa, bien por efecto de la lex commissoria (D. 19.2.22.pr.), bien por el contrario consensu (p. 419).

92 «Habiendo convenido al vender un fundo que, hasta el pago total del precio, el comprador tendría en arrendamiento el fundo por cierta renta ¿deberá acaso hacerse cancelación de esta renta una vez que se haya pagado el precio? Respondí: exige la buena fe que se haga lo convenido, pero no debe pagar al vendedor más que en proporción al tiempo que se difirió el pago del precio». Sobre este fragmento, MOHINO, A. «A propósito de D.19.2.20.2...», p. 423: «Conforme a la buena fe dos serían las posibles soluciones: o bien la continuación con pago de la renta convenida durante el plazo fijado o bien el fin del arriendo con la consiguiente cancelación de la renta pactada. La seunda solución, que es más acorde con la opinión de Javoleno, es la que fue adoptada por los compiladores justinianeos al interpolar la afirmación aclaratoria sed non amplius...» Para D. DAUBE («Tenancy of parchaser...», pp. 79-80) se trata de una 
En este texto Javoleno expone el mismo supuesto de hecho que hemos visto en los textos anteriores: una compraventa con precio aplazado seguida de un arrendamiento. Contrariamente a lo que se plantea en el siguiente fragmento, en este se analizan las consecuencias del pago del precio aplazado, particularmente si el vendedor tiene derecho a seguir exigiendo el pago de la renta arrendaticia hasta el fin del período contractual. En sentido estricto la respuesta sería afirmativa, al ser la compraventa y el arrendamiento dos contratos independientes. Sin embargo, Javoleno considera que, al ser ambos contratos de buena fe, debe estarse a lo convenido y el arrendador no debe poder reclamar rentas por el tiempo posterior al pago del precio de la compraventa.

Paulus 34 ad ed. D. 19,2,22pr.: Item si pretio non soluto inempta res facta sit, tunc ex locato erit actio ${ }^{93}$.

En este fragmento se analizan los efectos del impago. Se presupone que se ha pactado la lex commissoria, puesto que la cosa ha devenido incomprada. Es obvio que tras la resolución sobrevenida de la compraventa, al vendedor sólo le queda la actio locati para exigir las rentas impagadas. ${ }^{94}$

compraventa con las prestaciones aplazadas: «La venta y el arrendamiento se celebran aquí al mismo tiempo; se ha fijado una fecha en la cual ha de pagarse el precio de compra y B, el comprador, arrienda el fundo por el tiempo que medie entre ese mismo momento y la fecha».

${ }_{93} \mathrm{Al}$ respecto, DAUBE, D. «Tenancy of purchaser...», p. 427. De acuerdo con el autor, mientras en el Derecho clásico la relación de arrendamiento se activaba con el impago de un plazo de la venta (instalment), de tal manera que si antes podía exigir el precio ex vendito, después del impago lo exigiría ex locato, en el régimen justinianeo, más protector de los intereses del comprador, el arrendamiento finaliza igualmente con el impago y el vendedor sólo puede exigir ex locato las rentas insatisfechas con anterioridad. Este cambio también lo aprecia en Iavolenus 11 epist. D.19,2,21. Por su parte, KASER, M. / KNÜTEL, R. RPR, p. 207, aplican a este caso el mismo comentario que dedican a Paulus 34 ad ed. D. 19,2,20,2; vid. nota 91. Sobre esta cuestión específica, KNÜTEL, R. "Kauf und Pacht bei Abzahlungsgeschäften im römischen Recht», en Studien im roemischen Recht: Max Kaser zum 65. Geburtstag gewidmet von seinen Hamburger Schülern (hrsg. von Dieter Medicus), Duncker Humblot, Berlín,1973, pp. 33 ss.

${ }^{94}$ MOHINO, A. «A propósito de D.19.2.20.2...», p. 422: «Poniendo en conjunción los dos textos de este autor [Paulo] procedentes de su libro 34 de comentarios al edicto parece que resuelta la venta con pacto de arrendamiento en virtud de lex commissoria todos los efectos del contrato habrían desaparecido, que cualquier otro derecho que eventualmente quisiera hacer valer el vendedor debería ser exigido a través de laactio locati». La autora apunta además que la conjunción item cobra todo su sentido si se considera que los compiladores situaron el texto de Juliano entre los dos textos de Paulo. 
Hasta ahora hemos visto ejemplos de combinaciones de venta y arrendamiento. A continuación nos referiremos a los supuestos aludidos por la doctrina en los que la cosa se entrega en precario:

Paulus 10 ad sab. D. 39,2,38pr.: Emptor aedium ante traditam sibi possessionem ideo inutiliter stipulatur, quia venditor omnem diligentiam ei praestare debet. tunc certe utiliter stipulatur, cum omnis culpa a venditore aberit, veluti si precario emptori in his aedibus esse permisit custodiamque ei afuturus tradidit.

Ulpianus 32 ad ed. D. 19,1,13,21,: Possessionem autem traditam accipere debemus et si precaria sit possessio: hoc enim solum spectare debemus, an habeat facultatem fructus percipiendi.

En estos fragmentos se pone de manifiesto -para nuestra extrañeza- la condición de possessor del precarista, en el primer caso para hacerle correr con el riesgo de pérdida al entender transmitida la posesión, salvo mala fe del vendedor o estipulación en contrario. En el segundo texto, traído a colación de lo que se debe al vendedor que ejercita la acción de venta, se dice que se es poseedor aunque la posesión sea a título de precario -el empleo de la conjunción concesiva es un reconocimiento implícito de que normalmente el precarista no es poseedor- con tal de que tenga la facultad de percibir los frutos (siendo un precarista).

Pues bien, dejando de lado la cuestión de si el precarista posee o no, lo cierto es que quedan testimonios de la combinación de compraventa y precario como medio de garantizar los intereses del vendedor:

Ulpianus 2 resp. Dig. 43.26.20: «Ea, quae distracta sunt, ut precario penes emptorem essent, quoad pretium universum persolveretur: si per emptorem stetit, quo minus persolveretur, venditorem posse conse$q u i »{ }^{95}$.

${ }^{95} \mathrm{Al} \mathrm{respecto,} \mathrm{DAUBE,} \mathrm{«Tenancy} \mathrm{of} \mathrm{purchaser...»,} \mathrm{p.} \mathrm{83;} \mathrm{también} \mathrm{KASER,} \mathrm{M} \mathrm{/}$ KNÜTEL, R. $R P R$, p. 207: "Conviene destacar que el posclásico Ulpiano niega la libre revocabilidad del derecho (interdictum de precario) al vendedor que hubiera entregado la cosa en precario hasta el completo pago del precio ... siempre que el comprador pague o no pueda invocarse su mora (D.43,26,20). Aquí encontramos el embrión del derecho de expectativa del comprador con reserva de dominio.» No obstante, si bien es cierto que los romanos alcanzaban excepcionalmente el efecto práctico de no procurar la propiedad hasta el pago del precio, no puede afirmarse que su construcción coincida con la que el § 449 BGB presume -ist im Zweifel anzunehmen, dass das Eigentum unter der aufschiebenden Bedingung vollständiger Zahlung des Kaufpreises übertragen wird (Eigentumsvorbehalt) - y que nuestra doctrina y jurisprudencia reconoce mayoritariamente, pues ni los romanos condicionaban suspensiva- 
El vendedor entrega la cosa al comprador en precario hasta que éste pague la totalidad del precio. Los efectos son los mismos que los señalados para la combinación de venta y arrendamiento: ${ }^{96}$ en ambos casos se trata de una compraventa de contado en la que el cumplimiento de las prestaciones es simultáneo, pero diferido en el tiempo.

De todos estos textos pueden deducirse las siguientes conclusiones:

a) En Derecho romano clásico existía un expediente de garantía del precio aplazado que se basaba en una hábil combinación de dos figuras jurídicas, una de ellas con potencialidad traslativa (causa dominii) y otra sin ella, como el arrendamiento o el precario, que se extinguía con el pago del precio. Si bien puede deducirse que el vendedor seguía como propietario hasta el pago del precio, tal circunstancia no se menciona expresamente, ni menos la explicación jurídica del paso de la propiedad con el pago. La doctrina ve en esta combinación de causas el pactum reservati dominii ${ }^{97}$, interpretación que no compartimos, pues de haber existido la posibilidad de reservarse la propiedad por pacto no tendría sentido el expediente indirecto de dar la cosa en arrendamiento o en precario, pues bastaría con entregar la cosa por causa de venta, reservarse la propiedad convencionalmente por el sugerido pacto y condicionar entre las partes la adquisición de la propiedad al pago del precio.

c) No se encuentran fuentes de las que se deduzca la admisibilidad de retardar convencionalmente los efectos de la traditio; más bien al contrario, abundan las que recalcan la vinculación entre entrega (aunque sea ficticia) y transmisión de la propiedad.

d) No se explica de modo satisfactorio cómo se hace valer proce-

mente la transmisión de la propiedad al pago del precio ni los alemanes o españoles celebran simultáneamente con la compraventa un arrendamiento, comodato o precario. 82.

${ }^{96}$ Sobre la identidad de los supuestos, DAUBE, D. «Tenancy of purchaser...», p.

${ }^{97}$ Por ejemplo, A. MOHINO (Pactos en el contrato de compraventa en interés del comprador, Dykinson, Madrid, 2006, p. 52). No obstante, la autora deja fuera de la categoría genérica del pacto de reserva de dominio la combinación de compraventa y precario «debido a que en las fuentes se ofrecen variados supuestos de compraventas con precario» (p. 56). Estando de acuerdo en que a través de la combinación de causas se conseguía el efecto señalado de la reserva de la propiedad, no creemos que hubiera ningún pacto en sentido estricto adicional a la celebración de los dos contratos (arrendamiento y compraventa) fuera, en su caso, del pacto resultorio suspensivamente condicionado al pago del precio por el que quizás se resolvería el arrendamiento. 
salmente el principal efecto del pactum: si ex nudo pacto actio non nascitur, ¿cómo recuperaría el vendedor la cosa respecto de un tercero causahabiente del comprador? Nótese que este tercero puede fundar en un tracto válido el habere de la cosa -su auctor (vendedor) la adquirió pro emptore ${ }^{98}$.

e) Si bien del análisis de los textos queda claro que los romanos acudieron a la combinación de causas para retener la propiedad, no se dice ni una palabra sobre el modo en que la propiedad pasa al comprador tras el pago. Ciertamente, puede presumirse que se entregaría la cosa brevi manu, pero esta razón no acaba de ser convincente, pues no encaja con los textos ni -mucho más importante-con la lógica de lo que representa la entrega de la condición de possessor. ${ }^{99}$

98 El vendedor podría ejercitar (cualquiera puede) la vindicatio rei, pero cabe que el segundo comprador le opusiera la excepción de cosa vendida y entregada (venditae et traditae). ¿Replicaría el vendedor ex pacto reservati dominii? Parece improbable; los efectos de los pactos sólo pueden hacerse valer frente a la contraparte. De hecho, el pacto consiste precisamente en la renuncia al ejercicio de una acción judicial (IGLESIAS, J. Derecho Romano, p. 404), como en el pactum de non petendo (se pacta el no ejercicio, p.ej., de la condictio indebiti) o el pactum de non praestanda (de praes dare $=$ dar caución) evictione (se pacta el no ejercicio de la actio auctoritatis, venditi, o ex stipulatio duplae...).

${ }^{99}$ La entrega brevi manu es la explicación que adopta A. MOHINO (Pactos en el contrato de compraventa, p. 79), y apoya su argumento en uno de los fragmentos más representativos al respecto (D.41,1,9,5=I.2,1,44), donde se dice que igualmente se transmite la propiedad si se vende a otro lo que ya tenía por arrendamiento, comodato o depósito. La razón aducida en ambos textos es que el vendedor consiente que la tenga en su poder por causa de compra. Cabe plantear una objeción formal y otra de fondo: i) formalmente, los textos que prevén la traditio brevi manu no resultan necesariamente aplicables a la combinación de causas, pues simpre resuelven casos en que la venta o donación (causa dominii) se celebra con posterioridad al comodato, arrendamiento, depósito, o ¿por qué no?, precario (causa non dominii). Sin embargo, en la combinación de causas la compraventa se celebra con carácter simultáneo a la otra causa, y lo que se pretende es que la transmisión de propiedad se postergue, no hasta la celebración de un negocio traslativo -ya celebrado-, sino hasta que el vendedor así lo tolere, con lo que la transmisión de la propiedad dependería -si seguirnos los textos al pie de la letra- de su exclusiva voluntad. De hecho, en este sentido los siguió SAVIGNY para llegar a la doctrina de la abstracción. ii) En el fondo, en la traditio brevi manu se transmite la propiedad no porque concurra una entrega simbólica o porque el vendedor consienta que el causahabiente se haga propietario, sino porque este último tiene por fin una causa dominii que antes no tenía y que ahora puede alegar para prevalecer en un juicio vindicatorio. Lejos de la voluntad del trasferente, es la causa válidamente celebrada lo que le hace propietario -si el auctor lo era-. El hecho de ser detentador (possessor desde que tiene causa dominii) le beneficia además procesalmente. Por esto, en la combinación de causas es difícil admitir que el comprador no se haya hecho propietario, pues el impago del precio no obsta a la validez de la compraventa, que podría alegarse en juicio como prueba de propiedad. Si el vendedor pretende reservarse la propiedad por pacto habría de sugerirse la redacción de la excepción en la fórmula, o explicar procesalmente por qué tiene la cosa ex locatio conductio y no ex empto. 


\subsubsection{La lex commisoria}

En derecho romano clásico se admitió la posibilidad de pactar en el marco de una compraventa que si el precio no se pagaba en un plazo determinado el vendedor podría optar entre exigir el pago o bien dar por resuelta la venta. Este pacto recibió el nombre de lex commisoria. ${ }^{100}$

La opinión mayoritaria concibe la lex commisoria como un pacto resolutorio suspensivamente condicionado ${ }^{101}$. Ante el impago del comprador, el vendedor podría optar entre exigir el cumplimiento intempestivo de la obligación o resolver el contrato ${ }^{102}$.

Nada se dice en D.18,3 acerca de los efectos de la resolución de la compraventa sobre la propiedad del bien vendido, pero vista la regulación respecto al pactum llamado ad diem addictio (D.18,2) -de semejantes efectos ${ }^{103}$ - puede concluirse que la propiedad retorna ipso

${ }^{100}$ Ulpianus 32 ad ed. D. 18,3,4pr.: «Si fundus lege commissoria venierit, hoc est ut, nisi intra certum diem pretium sit exsolutum, inemptus fieret...». La resolución de la venta por efecto del impago, que a su vez tiene como consecuencia la recuperación por parte del vendedor de la condición de dominus por la anulación sobrevenida de la causa dominii del causahabiente se encuentra precisamente en uno de los fragmentos aludidos como prueba de la existencia del pactum reservati dominii: Paul. 34 ad. ed. D.19,2,22pr.: «Item si pretio non soluto inempta res facia sit...»

101 Ulpianus 28 ad sab. D. 18,3,1: «Si fundus commissoria lege venierit, magis est, ut sub condicione resolvi emptio quam sub condicione contrahi videatur»; de acuerdo con C.F. Von GLÜCK (Ausführliche Erläuterung..., p. 273) la doctrina mayoritaria adoptaría esta interpretación.

102 Ulpianus 32 ad ed. D.18,3,4,2: «Eleganter papinianus libro tertio responsorum scribit, statim atque commissa lex est statuere venditorem debere, utrum commissoriam velit exercere an potius pretium petere, nec posse, si commissoriam elegit, postea variare»; en contra, Hermogenianus 2 iuris epit. D. 18,3,7: "Post diem commissoriae legi praestitutum si venditor pretium petat, legi commissoriae renuntiatum videtur, nec variare et ad hanc redire potest.»

${ }_{103}$ Si bien Ulpiano se inclina por considerar la lex commissoria como un pacto resolutorio (Ulpianus 28 ad sab. D.18,3,1), en cuanto al ad diem addictio, lo deja a la libre configuración de las partes (Ulpianus 28 ad sab. D.18,2,2pr.); no obstante, expone a renglón seguido (Ulpianus 28 ad sab. D.18,2,2,1) que cuando se entiende que la venta es pura -resolutoriamente condicionada- el comprador puede usucapir y suyos son los riesgos, frutos y accesiones, luego se le tiene como propietario (si no lo fuera, sería en todo caso porque su auctor no lo fue -de ahí que pueda usucapir-, no porque carezca de causa adquirendi / dominii). De una opinión contraria es Pomponio; Von GLÜCK, C.F. Ausführliche Erläuterung..., p. 239, quien reconoce que la cuestión está abierta, sigue la doctrina de Acursio: pacto resolutorio. Sobre el estado actual de la cuestión, IGLESIAS, J. Derecho romano, p. 377, nota 143: «Según la opinión hoy prevalente, la in diem addictio es concebida por los clásicos antiguos bajo forma de condición suspensiva del contrato de compraventa...; Juliano es el primero en considerarla condición resolutoria o pacto resolutorio condicionado y, en fin, Ulpiano, según unos, o Justiniano, según otros, decide la cuestión teniendo en cuenta la voluntad de las partes». 
iure al vendedor ${ }^{104}$. Esto distingue claramente a la lex commissoria de la reserva de dominio, pues mientras que bajo el pacto de reserva de dominio la transmisión de la propiedad se condiciona suspensivamente al pago del precio, bajo el pacto de lex commisoria se somete a condición la eficacia del contrato y, en todo caso, antes de que el vendedor vuelva a ser propietario como consecuencia de la resolución del contrato, el comprador ya habría disfrutado -si acaso temporalmente- de la condición de propietario. Por consiguiente, desde un punto de vista funcional, la lex commissoria es un instrumento de garantía del pago del precio que compite con el expediente que hemos analizado anteriormente, consistente en entregar la cosa al comprador por una causa distinta de la compraventa (arrendamiento o precario).

\subsection{Conclusiones}

El ritual de la mancipatio es el primer mecanismo por el que se adquieren las cosas más significativas para la economía agraria de la Roma arcaica. El hecho de que Gayo en pleno siglo II d.C. se refiera a él como una imaginaria venditio y diga que el golpeo de la balanza con un trozo de bronce había tomado el lugar del pago del precio -quasi pretii loco-son suficientes indicios como para considerar que

${ }^{104}$ La dicción de la fórmula es ambigua: «ille fundus centum esto tibi emtus, nisi si quis intra Kalendas Ianuarias próximas meliorem conditionem fecerit, qua res a domino habeat», pues tanto cabe interpretar que pasa la propiedad del vendedor al tercero -mejor postor- como que pasa del primer comprador al segundo; no obstante, algunas opiniones ofrecen más elementos de juicio a favor de la segunda opción; así, Ulpianus 17 ad ed. D. 6,1,41: «Si quis hac lege emerit, ut, si alius meliorem condicionem attulerit, recedatur ab emptione, post allatam condicionem iam non potest in rem actione uti.» A contrario, antes del ofrecimiento del tercero se le tenía por propietario; también Ulpianus 28 ad sab. D.18,2,4,3: «ex quo colligitur, quod emptor medio tempore dominus est: alioquin nec pignus teneret.». Von GLÜCK, C.F. Ausfürhliche Erläuterung..., p. 285 afirma que «el comprador ha de devolver la cosa con todas las pertenencias y los frutos adquiridos», pero no precisa el remedio jurídico; cabe pensar en el ejercicio de la reivindicatio, pues el mismo autor afirma que el comprador pierde su derecho "como si el contrato nunca se hubiese celebrado»; también DAUBE, D. «Tenancy of purchaser (Digest 19.2.21)», Cambridge law Journal, vol. 10, 1948, p. 78, para quien la venta deviene nula, basándose en Paulo (Item si pretio non soluto inempta res facta sit)». Finalmente, de acuerdo con E. SANDMANN (Zur Geschichte des Eigentumsvorbehalts..., pp. 9-10) el pacto de lex commissoria condicionaba suspensivamente el contrato en tiempos de Sabino y resolutoriamente tras Juliano. A su juicio, el hecho de que la propiedad no revirtiera automáticamente desaconsejaba su utilización y, de hecho, su papel fue decayendo en la Glosa a favor de las formas híbridas de entrega a las que hemos aludido en el epígrafe anterior. De hecho, a juicio del autor, el espacio que deja la lex commissoria lo ocupa precisamente el pactum reservati dominii. 
por medio de la mancipatio se celebraba una venta de contado, con un intercambio simultáneo de cosa por precio, sin perjuicio de que, ya en época de las doce tablas, pudiera aplazarse el pago y adquirir el comprador sin embargo la propiedad si hubiera dado una prenda o un garante (Tabla VII,11). Si bien el ritual de la mancipatio -y el presuntamente anterior de la in iure cessio- se conservaría durante toda la época clásica, lo cierto es que iría asumiendo nuevas funciones, como la de servir de cauce al aplazamiento del precio o incluso devenir finalmente un mecanismo abstracto de adquisición de la propiedad.

Por su parte, las cosas menos significativas en el marco de una economía agraria (res nec mancipi) se transmitían por la mera entrega, que es un modo de adquisición de ius gentium por ser común a todos los pueblos, pues nada es más lógico o acorde con la razón natural que las cosas se adquieran porque alguien quiere desprenderse voluntariamente de ellas a favor de otro. No obstante, el hecho de que no comparezcan testigos nos lleva a pensar que tampoco se celebraba el proceso de la otorificación para sustanciar grandes pleitos por una cosa que, al fin y al cabo, tampoco era de tanto valor.

No obstante, la traditio acabaría reproduciendo los efectos de la mancipatio a través de añadir estipulaciones, como la duplae -que hace las veces de la actio auctoritatis de la mancipatio- $\mathrm{y}$, de hecho, fue tomando paulatinamente su lugar a medida que el comercio se fue implantando entre romanos y latinos dentro de un ámbito geográfico que desbordaba con mucho la finalidad publicitaria de la mancipatio. Con la regulación de los ediles curules su régimen jurídico se acabaría estandarizando y las facultades que el vendedor pactaba por estipulaciones acabarían desembocando en el régimen general de la compraventa consensual.

De entre las obligaciones del vendedor cabe destacar, en su caso, la de indemnizar por la evicción, pues la entrega de la cosa no es una consecuencia necesaria del contrato de compraventa, ya que el vendedor puede retenerla en virtud de alguna causa -la más normal, usufructo-. Cuando cese el usufructo o la causa de que se trate, habrá de entregársela al comprador porque no puede alegar ninguna causa para retenerla, no porque tal obligación sea consecuencia del contrato de compraventa. De hecho, cualquier tercero que no tenga mejor fundamento jurídico (causa) debe entregar la cosa a su propietario.

Sí está el vendedor obligado, por el contrario, a hacer lo necesario para que el comprador adquiera la possessio sobre el bien vendido. La possessio no es sólo la posesión natural o tenencia, sino el presu- 
puesto jurídico que permite a su titular la retención y recuperación interina de la cosa y que suele utilizarse con la intención estratégica de situar a su titular en una posición procesal privilegiada -la de demandado- con vistas a parapetarse frente a un eventual juicio vindicatorio, tal y como ocurre con la usucapión, enervable si se demuestra que la cosa es hurtada.

No obstante, la adquisición de la condición de possessor tampoco depende de un comportamiento adicional del vendedor. Se es possessor desde que se demuestra que se ha tenido una cosa en el último año en virtud de una causa dominii -en nuestro caso la compraventa- (la causa demuestra que se ha obtenido la cosa sin violencia-sine vi-), pues ni el arrendatario, comodatario, o depositario lo son. De hecho, hasta que la noción de possessio no se extrapola a los derechos «limitados» -quasi possessio- la possessio coincide, esencialmente, con la tenencia en concepto de dueño, que no es un estado subjetivo, sino una circunstancia acreditable por la previa celebración una causa dominii.

Por tanto, puede decirse que para los romanos la posesión es básicamente un signo externo de propiedad que es complicado revertir en juicio. Este signo externo se basa generalmente, y como no puede ser de otra manera, en la tenencia o possessio naturalis (también habere, tenere, in possessione esse...) pero dado que hay casos en los que es manifiesto que una persona que tiene algo no aparece ante la conciencia social como un propietario -un durmiente a quien se le deja algo en la mano, un furiosus o un pupillus- y casos en los que ocurre lo inverso -el cazador que persigue una presa herida, el propietario de un animal que ha salido, quien ha perdido algo en un naufragio o incluso quien ha enterrado algo suyo y no se acuerda de dónde- los romanos recurrieron al criterio del animus para conceder la possessio allí donde no está la cosa o denegarla donde sí está, con tal de hacerla coincidir con la percepción social de pertenencia.

La cuestión de si el vendedor se obliga a transmitir la propiedad se antoja especialmente complicada, pues los romanos no definen el concepto de propiedad. A pesar de que en las fuentes no se encuentre una definición general de proprietas o dominium sí aparecen otras formas de referirse al concepto que nos pueden resultar de utilidad, sobre todo, el artículo posesivo y el empleo del caso genitivo (lo cual también ha sido apreciado por algún filólogo), y dado que sí disponemos de fragmentos en que los que se dice meridianamente que «es mío lo que subsiste de una cosa mía, cuyo derecho de vindicación tengo» (Cel. 18 D. 6,1,49,1) o que «se entiende que tenemos una cosa en nuestros bienes cuando poseyéndola tenemos excepción, o, perdiéndola, 
acción para recuperarla» (Mod. 7 reg. D. 41,1,52) podemos afirmar con seguridad -y no descubrimos nada nuevo- que el romano identifica la propiedad con la facultad de prevalecer en un juicio vindicatorio, dejando quizá en un segundo plano el análisis de las facultades que le puedan corresponder al propietario, pues ello exige un ejercicio de definición conceptual que los juristas romanos clásicos no consideraban necesario ni útil. En todo caso, hay pruebas de que ya en el Derecho posclásico se atribuyó a la propiedad el rasgo de la perpetuidad -que probablemente siempre se tuvo en mente-, tal y como puede deducirse de que Constantino prohibiera las ventas clandestinas sin insinuatio $\rightarrow$-cuando ... dejando a un lado la luz de la verdad y sin pensar en la perpetuidad del dominio... se encaminan precipitadamente a que de cualquier modo y en no sé qué subterráneo se celebren prácticas...»- o de que más tarde el emperador Zenón sentenciara que un arrendamiento a perpetuidad se confundiría con la venta (acuñando el nombre de emphyteusis). En cualquier caso, no se encuentran en las fuentes conceptos equivalentes al de la vocación de generalidad de las facultades del propietario o la elasticidad, si bien ya se habla de nuda propiedad en el Derecho clásico.

Por tanto, la pregunta de si a juicio de los romanos el vendedor está obligado a transmitir la propiedad es anacrónica y peligrosa, pues presupone la extrapolación de concepciones modernas que, además, adolecen de un alto grado de vaguedad. No obstante, si tratamos de razonar como un romano a juzgar por los elementos que encontramos en las fuentes y sobre todo, vinculando los fundamentos del proceso vindicatorio con el concepto de propiedad, podríamos decir que el vendedor se obliga o no a transmitir la propiedad en función de si se obliga o no por la evicción, pues transmitir la propiedad no es otra cosa que situar al causahabiente en una posición de irreivindicabilidad. Si el auctor traía causa de un tracto impecable y le da al causahabiente una causa del dominio válida, le habrá transmitido la propiedad. En caso contrario -hurto o causa resuelta, iniusta o nula (nulla causa significa en realidad que no hay causa)- no se la habrá transmitido. De esto se sigue que el hecho de transmitir o no la propiedad es en cierta manera algo que escapa el control del vendedor, ya que éste puede desconocer que en realidad no es propietario.

Si la transmisión de la propiedad no está en manos del vendedor, ¿cómo entender que se obligue por algo que no controla? -objetan algunos-. Nosotros entendemos que no hay ningún impedimento para aceptar tal responsabilidad. En la mayoría de los casos el vendedor se obliga por evicción, pues no en vano la asunción del riesgo de la ajenidad de la cosa está incluida en el precio. De hecho, el vendedor sólo 
responderá de la evicción si se hubiera pagado el precio o dado prestación equivalente-Ulpianus 32 ad ed. D.19,1,11,2: si quidem dominus fuit venditor, facit et emtorem dominum, si non fuit, tantum evictionis nomine venditorem obligat, si modo pretium est numeratum, aut eo nomine satisfactum.-

En cuanto al pago del precio, no cabe ninguna duda de que en el Derecho romano clásico no se exigió como requisito para la validez del contrato de compraventa. Precisamente una de las apreciaciones más constatadas y compartidas en la doctrina romanista es que el periodo clásico se caracteriza por una distinción entre los efectos obligacionales de los contratos y los «reales» de la entrega, mientras que en el Derecho posclásico por efecto de la decadecia de la jurisprudencia se vuelve a la regla arcaica de exigir el pago para transmitir la propiedad. Ahora bien, esto no representa necesariamente un apoyo para los que entienden que el vendedor retiene la propiedad habiendo entregado la cosa, pues puede entenderse perfectamente que el vendedor retiene la tenencia material de la cosa hasta que se le entregue el precio, volviendo así a una generalización de los negocios de contado -el trueque-, algo nada descabellado habida cuenta de la inseguridad reinante en este periodo. Aun así, de algunas constituciones posclásicas se deduce claramente que el vendedor impagado puede ejercitar la actio pretii (venditi), pero en ningún caso la reivindicatio (C. 4,38,8/9), lo cual contradice flagrantemente la supuesta regla de que es necesario el pago para transmitir la propiedad.

El único argumento que la doctrina arguye para justificar la necesidad del pago, incluso en el Derecho clásico, es un famoso fragmento de las Instituta (2.1.41) -J.M. Miquel ha afirmado con razón que no se puede hablar de la reserva del dominio sin tratar de este precepto-, que está alineado con otro de Pomponius (31 ad. Q. Muc. D.18,1,19) donde se reproduce con una ligera variación una regla ya presente en las XII Tablas (VII,11): las cosas se adquieren si se hubiera pagado el precio o satisfecho de otro modo al vendedor, como dando una prenda o un garante. Hasta aquí la regla decemviral, pero resulta que Justiniano añade como tercera excepción que el vendedor se hubiera fiado del comprador (si fidem emptoris secutus fuerit), dejando ciertamente en agua de borrajas la regla general que exige el pago del precio, o en su defecto prenda o garante. Ante esta excepción, quienes defienden que es necesario el pago para la transmisión de la propiedad han considerado que la adición justinianea es dispositiva y que el pacto por el que se desplaza es precisamente el pactum reservati dominii, que ha desaparecido de las fuentes sin dejar rastro. 
Esta interpretación no es convincente, pues pasa por considerar dispositivo lo que no encaja con las construcciones de cada cual e imperativo lo que sí encaja. Por otra parte, aunque el mencionado fragmento estuviera exento de contradicciones no aportaría por sí solo suficiente base como para considerar que bajo la vigencia del Derecho romano la transmisión de la propiedad exige el pago, pues está en disonancia con otros fragmentos de los Instituta-no digamos de las fuentes clásicas- referidos a la transmisión de la propiedad o a la compraventa y que para nada hacen referencia al pago del precio. Por ejemplo, Inst. II.1.40: «... y así, de cualquier género que sea la cosa corpórea, puede ser entregada, y entregada por su dueño se enajena.» Los pasajes referidos a la entrega brevi manu o a la entrega de llaves (II.1.44/45) tampoco mencionan el pago del precio, pero el fragmento más relevante se encuentra en Inst. 3,23, que regula la compraventa y del que se deduce que el contrato y la entrega bastan para transmitir la propiedad. A mayor abundamiento, la extravagancia del precepto ha sido reconocida por estudiosos del relieve de E. Levy, para quien la regla quedó obsoleta «tan pronto salió de la pluma», opinión que en la literatura más moderna ha secundado también $\mathrm{R}$. Zimmermann.

Por otra parte, no parece que en el tráfico económico romano hubiera necesidad de un pacto semejante al sugerido reservati dominii, pues existían otros mecanismos de garantía suficientemente desarrollados. Si bien el Derecho romano siempre tuvo preferencia por las garantías personales, lo cierto es que podría constituirse una hypotheca -término romano equivalente a una prenda sin desplazamiento- sobre el bien vendido o incluso recurrirse al más frecuente pactum llamado lex commissoria, que funcionaría como una resolución retroactiva del contrato suspensivamente condicionada al pago del precio. De este modo la causa se anularía y en consecuencia el vendedor prevalecería con la reivindicatio sin que el comprador pudiera retenerla en virtud del contrato de compraventa, ya extinto.

No obstante, se ha defendido que los romanos sí conocieron el pacto de reserva de dominio, a la vista de ciertos pasajes en que se vende una cosa que se entrega en virtud de otra causa diferente. Con todo, siendo cierto que los romanos pudieron conseguir el efecto práctico de «reservarse el domino» celebrando simultáneamente un comodato, arrendamiento o precario y entregando la cosa en virtud de una estas causas -non dominii, por así decir-, lo cierto es que tales estrategias no equivalen a la construcción que mayoritariamente se asume hoy en día por la doctrina y jurisprudencia donde se admite la validez del mismo: condicionamiento suspensivo de la transmisión de 
la propiedad habiéndose celebrado una compraventa. Hoy falta ese segundo negocio que sí se encuentra presente en Roma; además, para los romanos es totalmente extraño que la traditio pueda condicionarse, pues esta no es otra cosa que la mera entrega.

Lo expuesto en los párrafos precedentes permite concluir que la compraventa romana clásica tiene los rasgos fundamentales que hacen posible una situación de especial riesgo para un vendedor: es posible que un vendedor haya entregado la cosa al comprador pero no haya percibido íntegro el precio, de modo que, en caso de insolvencia del comprador, el vendedor corre el riesgo de quedarse sin cosa y sin precio (al menos en parte). Los presupuestos para que pueda plantearse este problema son tres:

a) La compraventa es un contrato consensual que no exige para su perfección el pago del precio. Ello permite a las partes pactar el aplazamiento del pago.

b) El contrato de compraventa tiene eficacia puramente obligacional y no trasmite por sí misma derechos reales. Este rasgo del contrato permite el aplazamiento de la transmisión de la propiedad de la cosa vendida para un momento posterior a la celebración.

c) El cumplimiento de las prestaciones de comprador y vendedor no tiene por qué ser simultáneo.

En el derecho romano el referido problema no se puede resolver mediante un pacto por el que el vendedor se reserva el dominio sobre la cosa en tanto no se pague íntegramente el precio. Este pacto no es posible porque no se admite la suspensión del efecto transmisión de una traditio ex iusta causa por mero pacto entre las partes. Esto implicó que los romanos tuvieron que recurrir a expedientes complejos para proteger al vendedor en los casos en los que la cosa se entregaba antes de que el precio estuviese totalmente pagado. Al parecer dos fueron las soluciones principales: i) por un lado se permitía que el vendedor transmitiese la posesión al comprador por una causa distinta de la compraventa (arrendamiento, precario), considerándose en tal caso que la propiedad no se transmitía porque la entrega no se había hecho por causa de venta; ii) La segunda solución fue el pacto llamado lex commissoria, en virtud del cual las partes acordaban que el impago del precio permitiría al vendedor resolver la venta. La resolución implicaría la desaparición sobrevenida de la iusta causa de la traditio y la recuperación, por parte del vendedor, de la propiedad sobre la cosa vendida. Estos dos expedientes tienen una función idéntica a la reserva de dominio, pero operan técnicamente de forma muy distinta. El origen de 
la reserva de dominio tal como la conocemos hoy debemos buscarlo en las doctrinas construidas en la Edad Medida sobre la base de textos romano-justinianeos y de la praxis comercial.

\section{LA TRANSMISIÓN DE LA PROPIEDAD}

\section{El concepto de dominio y su transmisión en las diferentes etapas del Derecho Romano}

El mecanismo de la retención de dominio como garantía del pago del precio nace en la doctrina romanística medieval estrechamente vinculado a las concretas vías de transmisión de la propiedad existentes en el Corpus justinianeo. Al configurarse la transmisión de la propiedad por causa de venta en el derecho romano-justinianeo de modo totalmente independiente del pago del precio se posibilita la creación de una situación de riesgo para el vendedor que ha entregado la cosa pero que todavía no ha cobrado el precio. El mecanismo de transmisión de la propiedad, por lo tanto, es uno de los factores clave en la creación del problema, pero, como veremos, también es el mecanismo en el que se busca la solución.

El lector no encontrará en las páginas que siguen un estudio exhaustivo del problema de la propiedad y de su transmisión en el derecho romano con una exégesis individualizada de todos los testimonios disponibles. Aquí nos limitaremos a analizar los rasgos generales de la traditio ex iusta causa e intentaremos establecer el margen de libertad que se concedía a las partes para configurar este acto y para modular sus efectos.

\subsection{Derecho romano clásico}

1.1.1. La transmisión de la propiedad a través de la mancipatio e in iure cessio

La mancipatio -de manu capere ${ }^{105}$ - es el ritual a través del que se articulaban originariamente los intercambios de los factores pro-

105 G. 1,121: "adeo quidem, ut eum, qui mancipio accipit, adprehendere id ipsum, quod ei mancipio datur, necesse sit; unde etiam mancipatio dicitur, quia manu res capitur ... / y hasta es necesario que el que los compra coja el objeto que se le vende, de donde viene el nombre de mancipación, pues se coge la cosa con la mano.»; ROYO ARPÓN, J.M. Palabras con poder, p. 69. 
ductivos más relevantes en una economía agraria ${ }^{106}$. En su origen escenifica un trueque de una res mancipi por un precio -en bronce- que se entregaba simultáneamente. El accipiens -ad-capere-se apoderaba ${ }^{107}$ públicamente mientras proclamaba su pertenencia -...meum esse aio...- y el mancipio dans se allanaba sin poner en cuestión tal pronunciamiento, sin "contravindicar»" ${ }^{108}$. En la in iure cessio encontramos la misma afirmación solemne de pertenencia ante idéntica pasividad del propietario ${ }^{109}$; ésta difiere de la mancipatio en que resulta apta para transmitir cosas incorporales y en la sustitución de los testigos por la presencia de un magistrado. ${ }^{110}$

La compraventa con pago de precio aplazado se articularía a través de la mancipatio nummo uno, en la que el pago se simbolizaba con el golpeo del bronce en la balanza, conservándose así el ritual per aes et libram a pesar de que ya no se pese el bronce. De hecho, el rito del bronce y la balanza acabaría utilizándose para transmitir las cosas en virtud de cualquier causa; de ahí que Gayo -ya en el S.II dChable de la mancipatio como una imaginaria venditio ${ }^{111}$.

106 G. 2,14 : "Mancipi sunt velut fundus in Italico solo, item aedes in Italico solo, item servi et ea animalia, quae collo dorsove domari solent, velut boves, equi, muli, asini, item servitutes preadiorum rusticorum...»; el ritual de la mancipatio se describe en G. 1,119. Sobre la mancipatio en general, BURDESE, A. DPR, pp. 301 ss.

107 D'ORS, Á. DPR, p. 210, considera, de hecho, que en toda forma adquisitiva subyace un acto de apropiación: ad capere>accipere; manu capere>mancipatio; manu habere $>$ manubiae (botín de guerra);ob-capere>occupatio; usu capere> usucapio; per-capere>perceptio (de frutos); prae-capere (legado per praeceptionem); ius capere (capacidad legal para adquirir mortis causa). Parece que esto es cierto en tiempos arcaicos, pero tal necesidad de apoderamiento fáctico se irá relativizando con el tiempo, entre otras razones, i) por la introducción de la noción de «derecho limitado» (sobre el origen del concepto, KASER, M. Eigentum..., p. 16); piénsese en la mancipatio/in iure cessio en que el accipiens se apodera de la cosa en otro concepto, reteniendo la propiedad el mancipio dans (G. 2,33: «in mancipanda proprietate detrahi potest»); ii) por las formas fingidas de tradición, en que el apoderamiento brilla por su ausencia, ya sea porque el accipiens ya tenía la cosa consigo, porque el hurto queda excluido de facto (traditio clavium apud horrea) o porque sea socialmente notorio el traslado dominical y el accipiens prescinde de la cautela de la toma posesoria.

108 Sobre tal "contravindicatio», BURDESE, A. DPR, p. 86 -en el marco de un proceso-; p. 305 -respecto a la in iure cessio-; el autor no habla de una ausencia de contravindicatio en la mancipatio.

109 G. 2,24: «deinde postquam hic vindicaverit, praetor interrogat eum, qui cedit, an contra vindicet; quo negante aut tacente tunc ei, qui vindicaverit, eam rem addicit; idque legis actio vocatur...»; similar estructura presenta la adopción; G.1,134: «qui adoptat, vindicat apud praetorem filium suum esse, et illo contra non vindicante a praetore vindicanti filius addicitur».

${ }^{110}$ De acuerdo con A. FERNÁNDEZ DE BUJÁN (DPR, p. 436) es posible que la in iure cessio fuera un instituto anterior a las XII Tablas, que se habrían limitado a testimoniar su existencia, si se acepta lo indicado en FV. 50.

111 G. 1,113/119. 
El hecho de que la mancipatio -en cualquiera de sus versiones- se celebre en presencia de los cinco testigos y del libripens cumple una función publicitaria evidente; 112 cada mancipatio será un eslabón de la cadena de transmisiones que todo prospectivo adquirente habrá de recorrer para cerciorarse de la continuidad del tracto, al menos hasta agotar los plazos de la usucapio ${ }^{113}$.

\subsubsection{La transmisión de la propiedad a través de la traditio ex iusta causa}

Frente a las res mancipi ${ }^{114}$ se contraponen las nec mancipi, que representan la mayoría de los bienes intra commercium. A diferencia de lo prescrito para las res mancipi, la propiedad de una res nec mancipi se procura al accipiens a través de la mera entrega fundada en una iusta causa acquirendi hecha por quien ostenta el poder de disposición (potestas alienandi) sobre la cosa-si tradens dominus esset- ${ }^{115}$. La concurrencia de causa dominii es vital, pues son las únicas que pueden ser alegadas en un juicio vindicatorio como eslabones de un tracto sucesivo en que fundar la propiedad. Además, quien no tenga la cosa en virtud de una de tales causae no gozará del favor de la usucapio, que será frecuentemente el mecanismo procesal por el que un tenedor de una res nec mancipi prevalezca frente a los demás, pues éstas -desde tiempos de las XII Tablas ${ }^{116}$ - se usucapen en un año.

112 KASER, M. / KNÜTEL, R. RPR, p. 120: «a lo largo del periodo clásico la mancipatio retrocede paulatinamente, pues sus efectos publicitarios ya no tienen efecto en las grandes ciudades a través de los cinco testigos. Pierde gran parte de su significado desde que la entrega informal de la cosa es protegida como una propiedad honoraria. En la época clásica tardía (incluso antes en las provincias) hasta se documentaba, pero la mancipatio por sí misma había perdido validez. En el periodo posclásico desparece fulminantemente. Ya hacía tiempo que no se utilizaba cuando Justiniano la elimina de las fuentes clásicas.»; KASER, Eigentum..., p. 209; sobre su función publicitaria también ZIMMERMAN, R. The law of obligations, p. 271.

113 G. 2,44=D.41,3,1: "Quod ideo receptum videtur, ne rerum dominia diutius in incerto essent, cum sufficeret domino ad inquirendam rem suam anni aut biennii spatium, quod tempus ad usucapionem possessori tributum est».

114 G. 2,14/18.

115 D'ORS, Á. DPR, p. 225: «La falta de una causa adquirendi de éstas [credere, solvere, emere,donare,dotem dare] hace que la traditio resulte inoperante para hacer propietario al accipiente...».

116 Tabla VI, III: «ceterarum rerum omnium ... annus est usus». Sobre el significado de auctoritas en la regla «usus auctoritas fundi biennium esto», FUENTESECA, P. «el titulus y el modus de los glosadores boloñeses...», p. 5734, donde recoge la visión al respecto de Th. Mommsen y P.F. Girard, aceptada también por M. Kaser (auctoritas equivale a la responsabilidad del auctor). Él se manifiesta en contra y coincide -con 
Es presumible que la traditio ex iusta causa se haya utilizado mucho antes de ser recogida en las fuentes, ya que se trata del sistema transmisivo más intuitivo y ágil que puede concebirse (no en vano, Gayo la califica como de ius gentium / nautalis aequitas) ${ }^{117}$. Sin embargo, y a diferencia de lo que ocurría con la originaria mancipatio, el tradens no respondía de la evicción; de lo contrario no se explicaría la posterior práctica de estipular el duplum o la cantidad que fuera para el caso de la vindicación satisfactoria de un tercero ${ }^{118}$. De hecho, no parece que originariamente una res nec mancipi fuera susceptible de vindicatio, pues ni se llamaba a testigos (rogatio) ni el auctor venía obligado a defender la causa ${ }^{119}$.

El pretor extiende el régimen de transmisión de la propiedad por traditio ex iusta causa a las res mancipi. En estos casos el adquirente no se hace propietario civil (dominus ex iure Quiritium) sino sólo pretorio (in bonis habet) hasta que complete la usucapión. Mientras está usucapiendo el pretor le protegerá frente a terceros mediante acciones y excepciones pretorias.

Gayo subrayó que, en estos casos, la propiedad se desdobla, dando lugar a dos propiedades ${ }^{120}$. Ni que decir tiene que hablar de la coexistencia de dos propiedades horroriza al purista y espanta al amante de la seguridad jurídica ${ }^{121}$. Si se concibe la propiedad básicamente como el

Noalilles- en que la estrecha relación etimológica entre «auctor» $\mathrm{y}$ «augur» lleva a concebir la «auctoritas» como la «concepción augural de la legitimidad pública» (p. 5745). No obstante, esta interpretación no explica la «aeterna auctoritas» del hostis, que se explica perfectamente como la obligación del extranjero de fundamentar completamente el tracto sucesivo, lo que responde a su vez al interés de los cives en que los extranjeros no se valgan de la ventaja procesal que ofrece la regla «usus auctoritas fundi bienium esto; ceterarum rerum annus est usus».

117 G. 2 rer. cott. D. 41,1,9,3.; TALAMANCA, M. IDR, 435: «La consegna manuale è il mezzo più spontaneo e più naturale per trasmettere ad altri la disponibilità di una cosa: come modo di trasferimento della disponibilità absoluta sulle cose risale-nell'esperienza giuridica romana- alla più remota antichità.»

118 BURDESE, A. DPR, p. 457.

119 Esta obligación sólo es propia de la mancipatio, lo cual se entiende fácilmente si se atiende a la función publicitaria del ritual, que facilita la reconstrucción del tracto sucesivo. Sobre esto KASER, Eigentum..., p. 104.

120 La formulación más clara,G. 2,40; vid. además, G. 2,88.

121 VALLET DE GOYTISOLO, J.B. «Determinación de las relaciones jurídicas referentes a inmuebles susceptibles de trascendencia respecto de terceros», en Estudios sobre derechos de cosas, I, $2^{\mathrm{a}}$ edición, Montecorvo, Madrid, 1985, p. 334: "Ya IHERING hizo notar que dos relaciones de propiedad no pueden existir sobre una sola y misma cosa (unidad de la cosa, unidad de derecho, teoría de la accesión), así como tampoco puede existir una sola relación de propiedad sobre dos cosas (pluralidad de cosas-pluralidad de propiedad).» Art. 2508 CC Argentina: «El dominio es exclusivo. Dos personas no pueden tener cada una en el todo el dominio de una cosa; mas pueden ser propietarias en común de la misma cosa, por la parte que cada una pueda tener.» 
derecho a tener una cosa con carácter tendencialmente perpetuo, resulta lógicamente imposible la coexistencia de dos propietarios sobre un mismo bien. Podrá haber varios copropietarios, pero nunca dos propietarios.

La necesidad de distinguir entre una propiedad ex iure Quiritium y una propiedad pretoria o bonitaria (in bonis esse / habere) ${ }^{122}$ fue consecuencia del otorgamiento ad hoc por parte del praetor de la acción publiciana al adquirente de una res mancipi que no hubiera sido entregada por mancipatio, sino mediante traditio ex iusta causa, obviándose así la publicidad que procuraba la celebración del ritual de la mancipatio ${ }^{123}$. De esta forma, y bajo la ficción de haber cumplido los plazos de la usucapio, se le daba al accipiens despojado acción contra otros tenedores y, además, remedios procesales para paralizar la reivindicatio / exceptio iusti dominii del dominus ex iure quiritium que se la entregó: ${ }^{124}$ respectivamente, exceptio rei venditae et traditae / replicatio doli- ${ }^{125}$.

La razón de ser de esta distinción se halla en la necesidad de arbitrar un remedio jurídico para tutelar al peregrinus cuando la expansión del imperio propició las relaciones comerciales con los ciudadanos romanos. No obstante, el creciente comercio entre los mismos romanos, favorecido por la extensión de la ciudadanía (S. I aC. a los aliados de la península y $212 \mathrm{dC}$ a todos los habitantes libres del imperio) y la privatización del ager publicus, propició a la postre la generalización de la traditio ex iusta causa+stipulatio duplae en detrimento de la mancipatio.

122 DIÓSDI. G. Ownership..., p. 169 y s., extrae de un estudio exhaustivo de las veces en que la expresión «in bonis esse o habere» aparece en las fuentes clásicas [sobre 47 pasajes] que no cabe hablar en sentido técnico de una «propiedad bonitaria» $\mathrm{u}$ «honoraria». De acuerdo con el autor, el término "propietario bonitario» se emplea en un pasaje del Comentario a las Instituciones de Justiniano atribuido a Teófilo [Theoph. Paraphr. 1,5,4]. La posterior "generalización teórica» la atribuye a la disposición dogmática de las escuelas orientales. Sobre el sentido de tales términos véase nota 34.

${ }^{123}$ ZIMMERMAN, R. The Law of Obligations, p. 271: "Todos estos actos estaban enderezados a la publicidad: los derechos reales, que potencialmente afectan a cualquiera (se hacen valer frente a cualquiera que retiene la cosa frente al titular legítimo) no podían adquirirse o transferirse en privado.»

${ }^{124}$ BURDESE, A. DPR, p. 299: «Perché si abbia dominium ex iure Quiritium occorre inoltre che esso si fondi su di un titolo di acquisto riconosciuto dal ius civile. Vi sono tuttavia ipotesi in cui, sulla base di un titolo di acquisto non riconosciuto valido dal ius civile, il ius honorarium assicura, tramite la concessione di appositi mezzi processuali, una tutela piena, erga omnes, analoga a quella del dominium ex iure Quiritium: si parla a questo proposito nelle fonti classiche di «in bonis habere» o «esse», dai moderni di proprietà pretoria o bonitaria...»

125 SANSÓN, M.V. La transmisión de la propiedad, p. 127; en cuanto a las razones que dieron lugar a la introducción de la acción publiciana, la autora suscribe la hipótesis de DIÓSDI (pp. 146,148). 
Los dos presupuestos de la mutación «jurídico-real» tanto para la propiedad civil de las res nec mancipi como para la pretoria de todas las cosas son los siguientes:

i) La traditio ex iusta causa adquirendi / dominii: Se entiende por traditio (de tradere) el mero traslado físico de la cosa, desnudo de toda connotación jurídica ${ }^{126}$, por causa habilis ad dominium adquirendum cualquiera de las que dan lugar a la transmisión del dominio (-art. 1952 CC-: que legalmente baste para transferir el dominio») y por iusta, acorde al ius ${ }^{127}$. La causa ha de ser válida ${ }^{128}$ y verdadera ${ }^{129}$.

126 KASER, M. «Zur iusta causa traditionis», BIDR 64 (1961), p. 62: «la traditio se caracteriza, individualmente considerada, como una mera entrega corporal, un acto real que en cuanto a lo jurídico es neutral»; DIEZ PICAZO, L. «La tradición y los acuerdos traslativos...», p. 556: «La datio rei o entrega de una cosa es, como ponen de relieve FERRINI y URSICINO ALVAREZ, un hecho en sí mismo incoloro y equívoco, que puede servir para realizar múltiples fines económicos de naturaleza profundamente diversa...».

127 Con el adjetivo de iusta no pretendieron los romanos trazar una categoría diferenciada en torno a las causas de adquirir, sino concretar para estos supuestos un requisito de carácter general; KASER, M. «Zur iusta causa traditionis», p. 95, no le atribuye otro significado que el genérico de no contravenir el Derecho: «La causa ha de ser iusta; lo cual significa, atendiendo al sentido habitual de iustus, que ha de estar de acuerdo con el Derecho positivo. Esta restricción se manifiesta claramente en que las iniustae causae, como la donación entre cónyuges y algunas otras relaciones de atribución patrimonial que contravienen prohibiciones, no son idóneas para producir el efecto traslativo"; también SERRANO SERRANO, «justa causa traditionis», RCDI 1934, p. 725. De hecho, las fuentes rara vez adjetivan de iustae a las causae adquirendi, pues parece ser algo que se presupone. Así, G. 2,87=D.41,1,10,1: ex traditione ... sive quid stipulentur vel ex aliqualibet causa-; 2,90 -proprietas quidem adquiritur nobis ex omnibus causis sicut per eos-; $G$. 2,91=D.41,1,10,3 -quod vero extra eas causas-; G. 2,92=D.41,1,10,4 -quod extra duas istas causas adquiritur-; G. 2,93=D.41,1,10,5 -ex omni causa per eum sibi adquirere potest-; 2.95 -nulla ex causa nobis adquiri posse- (aparece iusta, referida a la possessio); G. 2 rer. cott. D.41,1,9,4; G. 11 ad ed. provinc. D. 41,1,32:-etiam invitis nobis per servos acquiritur paene ex omnibus causas-; Iulianus 13 Dig. D.41,1,36; Paulus 54 ad ed. D.41,2,3,4 -sicut dominium non potest nisi ex una causa contingere-; Pomponius 26 ad q. muc. D.41,2,26 -vel ex emptione, vel ex donatione, vel qualibet alia ex causa-.

${ }_{128}$ A pesar de que, en general, no se adopte un término técnico para referirse a las causas por las que se adquiere, Ulpiano distingue la causa apta para la transmisión respecto de las demás con el oportuno adjetivo de causa dominii (Ulpianus 65 ad ed. D.41,1,46 -Non est novum, ut, qui dominium non habeat, alii dominium praebeat; nam et creditor pignus vendendo causam dominii praestat, quam ipse non habuit), si bien más atinado es todavía Paulo, quien la individualiza como adquirendi (Paulus 54 ad ed. D.41,2,3,21: "Genera possessionum tot sunt, quot et causae adquirendi eius, quod nostrum non sit, velut pro emptore, pro donato, pro legato, pro dote, pro herede, pro noxae dedito, pro suo, sicut in his, quae terra mareque, vel ex hostibus capimus, vel quae ipsi, ut in rerum nature essent, decimus; et in summa magis unum genus est possidendi, species infinitae»). En el Derecho común se acuña para las causas que dan lugar al dominio la perífrasis «causa habilis ad dominium transferendum», tal y como nos enseña MIQUEL, J. DPR, p. 180, quien la emplea también en p. 241 cuando explica la fiducia en el Derecho clásico «la finalidad económico social de garantía no es causa habilis ad dominium transferendum, y, por tanto, no puede constituir una iusta causa de la transmisión de la propiedad». Entre 
De la relevancia que se otorgue a la nulidad de la causa-después $t i$ tulus $^{130}$, finalmente «negocio jurídico» ${ }^{131}$ - se derivan dos modelos con-

nuestros humanistas, José FERNÁNDEZ DE RETES distinguía entre causas «temporales» (depósito, comodato, arrendamiento) y «perpetuas» (venta, donación, dación en pago, permuta, legado, adiudicatio et similes), según expone DE LOS MOZOS, J.L. «Crisis del principio de abstracción...», p. 1065, quien, por su parte, adjetiva la causa de adquirir como «inmanente» (p.1069), si bien en la página siguiente pierde abstracción y, retomando el llano lenguaje de Paulo, nos dice que «la compra venta no es el único título de adquirir [mi cursiva]» (en cuanto a iusta, el autor equipara iustus -con M. Kaser- a la licitud (p.1043)). KASER agrupa las causas de adquirir bajo el término «Zuwendungsvehältnisse» en "Zur iusta causa traditionis», pp. 86, 95, si bien el empleo de un término moderno para aludir a un concepto romano suele ser contraproducente. Curiosa la manera de expresarlo de SAVIGNY, tal y como se deduce de los apuntes de Wilhelm y Jackob Grim de las clases de 1803/04: «Wilhelm: Traditio gibt nur Eigenthum bei einer justa dominii acquirendi causa / Jackob: «Tradizion gibt nur Eigenthum nei einer justa dominio acquirendi causa». Tomado de FELGENTRÄGER, W. Friedrich Carl v. Savignys Einflu auf die Übereignungslehre, Druck von Reinhold Berger, Lucka, 1927. pp. 27-28. Retomando a los escolásticos, LUIS DE MOLINA (1536-1600) exige un título «apto para la transmisión», GARCÍA GOYENA, en el comentario al art. 548 del proyecto de 1851, puntualiza que por contrato ha de entenderse «los que sean traslativos del derecho de propiedad»; finalmente la base 20 de nuestro Código civil vuelve, de nuevo, a Paulo al señalar que «los contratos como fuentes de obligaciones serán considerador como meros títulos de adqurir en cuanto tengan por objeto la traslación de dominio o cualquier otro derecho a él semejante. (He tomado estos cuatro últimos ejemplos del trabajo de PÉREZ ÁLVAREZ, M.P. «La compraventa y la transmisión de la propiedad. Un estudio histórico.comparativo ante la unificación del Derecho Privado Europeo», Revista Jurídica de la Universida Autónoma de Madrid, 2006, pp.228-229).

129 KASER, M. «Zur iusta causa traditionis», p. 83 ss.: «a) la causa venditionis (G. 2,20 ;Inst.2,1,41) exige, como antes hemos extraído del paralelismo con la usucapio pro emptore, una compra válida ... b) También la causa donationis (G. 2,20; Inst. 2,1,41; 2,6,11) exige una donación válida (Paul. D.41,6,1pr)... c) lo mismo respecto de la causa dotis. La dotis datio como negocio de contado procura la propiedad ... d) la causa credendi presupone un mutuum válido ... e) un grupo adicional responden al caso en que se transmite una cosa para alcanzar un fin (ob rem, ob causam datum); si no se logra el resultado, corresponde la condictio ob causam datorum, lo cual presupone la transmisión de la propiedad...»

130 De acuerdo con KASER, M. ibidem, p. 91 -seguido por DE LOS MOZOS, J.L. ibidem p. 1060- la adquisición fundada en un título putativo (disenso en cuanto a la causa) resulta excepcional y sólo se ha admitido en casos particulares, tras una cuidadosa ponderación. Celso consideró tales casos como absolutamente excepcionales y finalmente Diocleciano exigió un verus titulus (C.7,29,4; 7,33,5). A este respecto es conocida la antinomia entre Ulp. D.12,1,18 -se dona dinero que se recibe en mutuo: no pasa la propiedad (mas tiene exceptio doli contra la condictio)- y Jul. D.41,1,36:-se dona dinero que se recibe como acreditado:pasa la propiedad-. Tampoco es admisible el llamado «negocio causal real» (Kausale dingliche Einigung), en virtud del cual se transmite la propiedad si las partes entregan y reciben en virtud de la misma causa, aunque ésta sea torpe. KASER, M. ibidem, p. 68 considera que entender la transmisión completamente desvinculada de la validez de la compra, de la donación, etc., es extraño al pensamiento romano. El siguiente paso lo dio F.C. Von SAVIGNY al postular la transmisión con base en la mera voluntad de las partes. Sobre la influencia de Jul. D. 41,1,36 en Savigny, KASER/KNÜTEL, $R P R$, p. $121 \mathrm{f}$.

131 KASER, M. / KNÜTEL, R. RPR, p.121. 
ceptuales: i) el causalista, que exige en todo caso la validez de la causa para la válida transmisión del dominio ${ }^{132}$ y ii) el abstracto, que postula la independencia entre la validez de la causa y la transmisión. No obstante, el hecho de que la torpeza de la causa otorgue al perjudicado por el enriquecimiento injustificado una condictio para recobrar la cosa matiza inter partes los efectos prácticos de tal doctrina ${ }^{133}$.

ii) La condición de dominus en el tradens (o potestas alienandi del representante): Si el tradens no fuera el dominus, aquél que reconstruyera satisfactoriamente un tracto sucesivo en que basar su derecho al habere (verus dominus) o alegue la consumación de los plazos de la usucapio sin que el demandado demuestre que la cosa es hurtada vencería en el juicio vindicatorio al accipiens. Siendo dominus el tradens, es claro que no puede prevalecer ningún tercero con el ejercicio de la reivindicatio. Por último, para cerrar coherentemente el sistema es importante no perder de vista los casos excepcionales en que el tradens no es el dominus pero actúa por cuenta de éste, bien porque le corresponde su representación legal ${ }^{134}$ o bien porque entrega la cosa ex iusta causa adquirendi con su consentimiento -voluntate domini-135.

\subsection{Derecho justinianeo}

Pasado el paréntesis del derecho vulgar, en el que es unánimemente admitida la borrosa la distinción entre «actos obligatorios y

132 ÁLVAREZ SUÁREZ, U. El problema de la causa ..., p. 22: «nosotros entendemos por causa el negocio jurídico normalmente precedente, en que la traditio encuentra su fundamento.»

${ }_{133}$ Si bien el modelo se desdobla en función de si se acepta o no que la causa putativa funde una transmisión de la propiedad.

134 En coherencia con el carácter abstracto de la transmisión, ésta es la opción que adopta el Código alemán ( $\$ 812$, pfo. $1^{\circ}, 1^{\text {a }}$ frase, caso $\left.1^{\circ}\right)$ : «Quien a través de una prestación de otro ... hubiera recibido algo sin causa jurídica está obligado a la restitución». Junto con ésta también se prevén la condictio ob causam finitam (§812 pfo. $1^{\circ}$, $2^{\mathrm{a}}$ frase, caso $1^{\circ}$ ) y la condictio in rem o causa data, causa non secuta ( $\S 812$ pfo. $1^{\circ}, 2^{\mathrm{a}}$ frase, caso $2^{\circ}$ ). Es decisivo para entender el concepto que en Alemania se tiene de propiedad -y en Roma respecto de la traditio solutionis causa- el hecho de que se considere que ya es propietario el accipiens aunque venga personalmente obligado a la restitución por la condictio.

135 Vid. FERNÁNDEZ DE BUJÁN, A. DPR, p. 438: «...como enseña Gayo, Instituciones 2.62-64, en ocasiones el propietario no puede enajenar y en otras, una persona sin ser propietario tiene potestad, potestas alienandi, para enajenar la cosa ... Como supuestos de personas que sin ser propietarias tienen potestad para enajenar, en determinadors casos, cabe citar al procurador, al tutor y al curador.» 
de disposición ${ }^{136}$, en el régimen justinianeo se dará valor universal al régimen de la entrega hecha por iusta causa. En algunos negocios sobre bienes valiosos se exigirá, sin embargo la documentación como forma solemne. ${ }^{137}$ Respecto de éstos la espiritualización de la entrega material no se debe en modo alguno a la asunción de la transmisión abstracta ${ }^{138}$, sino a la debilitación de la posición procesal del possessor ante la documentación de tales transmisiones ${ }^{139}$. Tan es así, que la entrega de la cosa quedaría perfectamente sustituida por la del documento ${ }^{140}$, relegando la traditio a una cláusula

136 Sobre la terminología empleada y la variada casuística es imprescindible el estudio de SANSÓN, M.V. La transmisión de la propiedad, pp. 16-24. En líneas generales -y dejándonos muchos matices- la autora distingue entre i) potestas alienandi (G. 2,62 -»poder de disposición autónomo no vinculado necesariamente a la titularidad del derecho de propiedad»(p.18)-, si bien también se habla de ius vendendi (Mod. D.50,16,109; C. $2,12,16$ ) ii) «voluntate domini»-»para referirse a la autorización del dominus como fundamento de la eficacia transmisoria de dominium del acto de enajención realizado por el no dueño» (pp.18-19); iii) finalmente, en virtud del iussum «se produce una identificación entre las personas del autorizante y del autorizado» (p.22).

137 Por todos, LEVY, E. West roman vulgar law, p. 127.

138 Sobre esto, véase el comentario a C.4,21,17 de ZAMORA MANZANO, J.L. La publicidad de las transmisiones inmobiliarias, Fundación beneficentia et peritia iuris, Madrid, 2004, p. 143: «el emperador parece otorgar libertad a los contratantes aludiendo a un régimen dispositivo según el cual las partes deciden si van a acogere a un sistema contracual escrito o puramtne consensual, en las compraventas, donaciones en las cuales no se exige la insinuatio por ser de cuantías inferiores a 500 solidi, e incluso en documentación de dación de arras».

139 De esta opinión es ÁLVAREZ SUÁREZ, U. El problema de la causa ..., pp. $41 \mathrm{s.:}$ «Lo que JUSTINIANO requiere para que tenga lugar el traslado de propiedad, es la «voluntad concorde de las partes sobre el hecho de la transmisión». Más abajo: «Pero su efectiva importancia [la de la abstracción] se destacó en la época posclásica, a medida que iba cobrando importancia la voluntad y la iba perdiendo la materialidad de los actos en que cristalizaba representa su triunfo definitivo». Nosotros seguimos laopinión de DE LOS MOZOS, J.L. "Crisis del principio de abstracción...», p. 1066, para quien la espiritualización no equivale todavía a la abstracción: «la práctica documental no adquiere el significado que cobra en otros Derechos europeos, sirviendo, en éstos, a favorecer el alcance real de la nuda voluntad, mediante el auxilium instrumentum o carta, con lo que, por una parte, se está labrando la posibilidad de la abstracción y, por otra, se está contribuyendo, al menos, a configurar el contrato real del Code civil, que , sin duda, tanto influyó en el ánimo del propio Savigny».

140 Sobre la función procesal de la possessio, COING, H. Europäisches Privatrecht, Band 1, C.H. Beck, Múnich, 1985, p. 281: «Además en la literatura los efectos de la posesión se resumen como sigue:

"quod in pari causa melior est conditio possidentis» (D. 50,17,120) [aquí hay una errata, el pasaje es el D. 50,17,128pr.: «In pari causa possessor potior haberi debet.» (Paulus 19 ad ed.)]

-que al poseedor le corresponde la presunción de que es propietario, esto es de que no debe demostrar su propiedad en un juicio petitorio y que ante la falta de prueba del demandante conserva la cosa poseída, v. C. 4,19,2; 3,32,28; Inst.4,15,4..»; MIQUEL, J. DPR, p. 211. 
de estilo notarial, tan superflua como pertinaz, que no se abandonará hasta trece siglos después, con la aprobación del Code ${ }^{141}$. La suerte de la vieja mancipatio e in iure cessio ya es conocida: marginadas por la práctica del comercio desde hace unos cuatro siglos, desaparecen de las fuentes. ${ }^{142}$

\subsection{Conclusiones}

Como hemos visto al tratar sobre la mancipatio y la traditio, el concepto de propiedad y su transmisión se entiende mejor atendiendo al proceso que a las elaboraciones dogmáticas. El término dominium aparece por vez primera en la ley de la contrarreforma agraria $(111 \mathrm{aC})$, posiblemente de la mano de Servio Sulpicio Rufo, pero los juristas romanos nos dicen con los pies más en la tierra algo tan preciso como sencillo: algo es nuestro si podemos prevalecer en un juicio con la vindicatio para recuperarlo. Sea porque actúa como demandante o porque se defiende como demandado, en los juicios sobre la propiedad las partes deben alegar la causa en virtud de la cual vindican la cosa. Tal causa, que constituye el fundamento jurídico en que fundan su expectativa de seguir teniendo la cosa, equivale en las sociedades primitivas a la mancipatio o in iure cessio. Así, quien puede demostrar que tiene una res mancipi porque la adquirió en el marco de alguno de estos rituales -llamando al auctor o apelando al magistrado ante el cual se tomó la cosa- enerva cuanto menos la sospecha de hurto que en un primer momento recaía sobre el tenedor demandado. Tal auctor llamaría a su vez al suyo, y así se irían sucediendo uno tras otro hasta llegar al que ocupó la cosa por vez primera -o a quien la fabricó- o hasta que se hubiera demostrado un tracto ininterrumpido durante dos años si se tratara de un fundo o de uno si se trata de las demás cosas -...usus auctoritas fundi biennium

141 LEVY, E. West roman vulgar law, p. 155: "Se habrían asombrado de las posibilidades que C. 8.53.1 les ofrecía para transmisión por traditio per chartam.»

142 ÁLVAREZ SUÁREZ, U. El problema de la causa..., p. 58: «El Code civil da estado legislativo a aquella situación práctica y a esta fundamentación teórica, acomodada tanto a la realidad, que PLANIOL puede decir en su Tratado que el único cambio que el Código produjo en las costumbres fue que los notarios dejaran de estimar necesario recoger en sus documentos las antiguas cláusulas de estilo»;

D'ORS, Á. DRP, p. 215: «Excepcionalmente se conserva en el Digesto (D.28,3,8,1) en relación con la emancipación». Precisamente, el hecho de sustituir la mancipatio (abstracta) por traditio (sin aludir simultáneamente a la causa) es uno de los argumentos -junto con Int. 2,1,40/41- que los defensores de la abstracción aducen; KASER, M. / KNÜTEL, R. RPR, p. 123. 
est, ... ceterarum rerum omnium ... annus est usus-. Si alguno de los auctores fracasara en defender la causa, el demandante se la llevaría y el despojado de la cosa demandaría a tal auctor por el duplum con la actio auctoritatis, pues se entendería que ha perdido la cosa y el precio por su culpa.

En tanto la noción abstracta de negocio consensual no se haya desarrollado, la mancipatio o in iure cessio serán, por llamarlo de alguna manera, "rituales autónomos de transmisión», siendo la mancipatio una venta -esto es una aplicación retrospectiva de un concepto posterior, pues el concepto de mancipatio es anterior al de venta- y la in iure cessio, igualmente, un allanamiento ante la afirmación del otro y que parece ciertamente más versátil. Pero llegará un momento en que por diversos factores el centro de gravedad se desplazará del ritual en sí a un negocio consensual concreto, pasando el ritual a asumir la función secundaria de ser un mero "acto de cumplimiento» -por inercia- de un negocio transmisivo anterior, que es ahora la verdadera causa. La obsolescencia de los rituales a favor de la más ágil traditio -que en muchos casos será prescindible, por las razones que ya indicamos- centrará la atención en la causa como elemento central sobre el que girará la transmisión de la propiedad.

Por tanto, si bien se mira, la cuestión de la transmisión de la propiedad tiene como núcleo central el estudio del concepto de causa, de causa del dominio, obviamente, porque entre todos los negocios jurídicos o causas hay algunos que son aptos para procurar el dominio -puntualmente aludidas en las fuentes como causa domini / adquirendi (velut pro emptore, pro donato, pro legato, pro dote, pro herede, pro noxae dedito... [Paulus 54 ad ed. D.41,2,3,21]) y otros que sólo dan lugar a lo que hoy llamamos «derechos limitados», que en ningún caso podrían alegarse en un juicio vindicatorio para pretender fundar la propiedad. La causa ha de ser además acorde a Derecho -iusta-, verdadera y válida. Por otra parte, la regla de que siempre haya de ser el propietario el que celebre la causa dominii está sometida a algunas excepciones, pues de la misma manera que hay propietarios que no pueden autónomamente disponer de sus cosas -pupilos, ausentes, locos, mujeres-, hay no propietarios que sí pueden disponer de lo ajeno, como los representantes en los casos citados o, por ejemplo, el acreedor pignoraticio -Ulp. 65 ad. ed. D. 41,1, 46: non est novum, ut, qui dominium non habeat alii dominium praebeat; nam et creditor pignus vendendo causam dominii praestat, quam ipse non habuit.-)

Hasta aquí el Derecho romano clásico, si bien la noción de que la propiedad se transmite por la entrega precedida de una iusta causa do- 
minii no cambia en el Derecho vulgar. Si acaso puede apreciarse que durante el Derecho posclásico la decadencia de la jurisprudencia da lugar a un cierto recelo en el tráfico y se impone un retorno a los negocios de contado, pero ello no implica que para la transmisión de la propiedad de las cosas vendidas sea necesario el pago del precio, sino que este es sólo un efecto visual del hecho de que la cosa no se entregara hasta la total satisfacción del mismo -iqué mejor garantía en momentos de incertidumbre jurídica!-. De hecho, la vigencia de la regla clásica se deduce del examen de algunas constituciones posclásicas en las que al vendedor insatisfecho se le concede la actio empti en vez de la reivindicatio, amén de que Diocleciano y Maximiano enuncian la regla con toda claridad: Traditionibus et usucapionibus dominia rereum, non nudis pactis transferuntur (CJ 2,3,20). Sí se da, sin embargo, una cierta modificación en el Derecho justinianeo, donde se el papel preponderante de la escrituración, obligada en ciertos negocios, relativiza la importancia de la entrega física de la cosa, que queda relegada, como ya hemos puesto de manifiesto, a una cláusula de estilo que no desaparecerá hasta que en el Code se prescinde totalmente de la misma.

\section{BIBLIOGRAFÍA:}

ÁLVAREZ, U. El problema de la causa en la tradición, Real Academia de Jurisprudencia y Legislación, Madrid, 1945;

BURDESE, A. Diritto Privato Romano, $3^{\text {a }}$ ed., Utet, Turín, 1990;

CALONGE, A. Evicción. Historia del concepto y análisis de su contenido en el Derecho romano clásico, Universidad de Salamanca, 1968;

CANDIL, F. Pactum reservati dominii, Centro de Estudios Históricos, Madrid, 1915;

CASTRO SÁEZ, A. «Notas sobre un paralelismo en la creación pretoria del derecho", RIDA 2000, 193-220; COING, H. Europäisches Privatrecht, Band 1, C.H. Beck, Múnich, 1985;

DAUBE, D. «Tenancy of purchaser and lex commissoria», RIDA 1958 (5), pp. 425-435;

DE LOS MOZOS, J.L. «Crisis del principio de abstracción y prespuestos romanistas de la adquisición del dominio en el Derecho español», ADC 1972, pp. 1027-1082;

DIEZ PICAZO, L. «La tradición y los acuerdos traslativos en el Dere- 
cho español», ADC 1966, pp. 555-573;

DIÓSDI, G. Ownership in Ancient and Preclassical Rroman Law, Akadémiai Kiadó, Budapest, 1970:

D’ORS, Á. Derecho Privado Romano, $8^{a}$ ed., Eunsa, Pamplona, 1986;

FELGENTRÄGER, W. Friedrich Carl v. Savignys Einflu auf die Übereignungslehre, Druck von Reinhold Berger, Lucka, 1927;

FERNÁNDEZ DE BUJÁN, A. Derecho Privado Romano, $3^{\mathrm{a}}$ ed., Iustel, Madrid, 2010; idem, El precio como elemento comercial en el emptio-venditio romana, Madrid, 1984;

FUENTESECA, P. «El titulus y el modus de los glosadores boloñeses. Clave interpretativa del asíndeton. Usus auctoritas (XII Tab. VI,3) y de la historia del concepto romano de la propiedad», en Estudios en homenaje al profesor Lus Diez-Picazo, t. IV, Thomson-civitas, Madrid, 2003;

GLÜCK, C.F. Ausführliche Erläuterung der Pandecten nach Hellfeld, Band 16,2, Erlangen, 1815;

IGLESIAS, J. Derecho Romano, $11^{\text {a }}$ ed., Ariel, Barcelona, 1998; KASER, M. Eigentum und Besitz im älteren römischen Recht, $2^{\mathrm{a}}$ ed., Böhlau-Verlag, Colonia-Graz, 1956; idem,»Neue Studien zum altrömischen Eigentum», SZ 1951 (68), pp.130-190; idem, Compraventa y transmisión de la propiedad en el Derecho Romano y en la dogmática moderna, Publicaciones de los seminarios de la facultad de Derecho de la universidad de Valladolid, (traducción de J. MIQUEL), 1962; idem, "Zur iusta causa traditionis», BIDR 64 (1961), pp. 61-97 ;

KASER, M. / KNÜTEL, R. Römisches Privatrecht, 18. Auf., C.H. Beck, Múnich, 2005;

LACRUZ, J.L. Elementos de Derecho Civil, tomo III, vol. I, Dykinson, Madrid, 2000;

LEVY. E. West Roman Vulgar Law. The Law of Property, American philosophical society, Philadelphia, 1951;

MIQUEL, Derecho Privado Romano, Marcial Pons, Madrid, 1992;

MOHINO, A. "A propósito de D.19.2.20.2 en relación con D.19.2.22.pr.», RIDA (45), 1998; idem, Pactos en el contrato de compraventa en interés del comprador, Dykinson, Madrid, 2006; 
PÉREZ ÁLVAREZ, M.P. «La compraventa y la transmisión de la propiedad. Un estudio histórico.comparativo ante la unificación del Derecho Privado Europeo», Revista Jurídica de la Universida Autónoma de Madrid, 2006, pp.201-248;

PLESCIÁ, J. «The development of the exercise of the ownership right in roman law», BIDR, 1985 (88), pp. 181-207;

RICCOBONO, S. «Traditio ficta», SZ (33), 1912, pp. 259-304;

ROYO ARPÓN, J.M. Palabras con poder, Marcial Pons, Barcelona, 1997;

SANDMANN, E. Zur Geschichte des Eigentumsvorbehalts in Deutschland, Marburg, 1972;

SANSÓN, Ma .V. La transmisión de la propiedad, Marcial Pons, Barcelona, 1998;

SERRANO SERRANO, «justa causa traditionis», RCDI 1934, pp. 721-737;

TALAMANCA, M. Istitutioni di Diritto Romano, Giuffrè, Milán, 1990; THOMAS, J.A.C. «Tenancy by purchaser», Iura 1959 (10), pp.103-109;

VALLET DE GOYTISOLO, J.B. «Determinación de las relaciones jurídicas referentes a inmuebles susceptibles de trascendencia respecto de terceros", en Estudios sobre derechos de cosas, I, $2^{\mathrm{a}}$ edición, Montecorvo, Madrid, 1985;

ZAMORA MANZANO, J.L. La publicidad de las transmisiones inmobiliarias, Fundación beneficientia et peritia iuris, Madrid, 2004;

ZIMMERMAN, R. The law of obligations, Juta \& C.H. Beck, Ciudad del Cabo / Múnich, 1990. 
